\title{
Ground-Water Hydrology and Simulation of Ground-Water Flow at Operable Unit 3 and Surrounding Region, U.S. Naval Air Station, Jacksonville, Florida
}

By J. Hal Davis

U.S. GEOLOGICAL SURVEY

Open File Report 98-68

Prepared in cooperation with the

DEPARTMENT OF THE NAVY

SOUTHERN DIVISION,

NAVAL FACILITIES ENGINEERING COMMAND

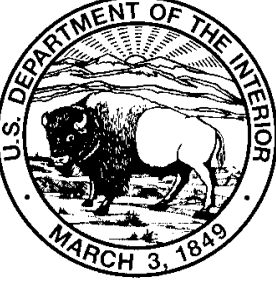




\title{
U.S. DEPARTMENT OF THE INTERIOR BRUCE BABBITT, Secretary
}

\author{
U.S. GEOLOGICAL SURVEY \\ Thomas J. Casadevall, Acting Director
}

The use of firm, trade, and brand names in this report is for identification purposes only and does not constitute endorsement by the U.S. Geological Survey.

For additional information write to:

District Chief

U.S. Geological Survey

227 North Bronough Street

Tallahassee, FL 32301
Copies of this report can be purchased from:

U.S. Geological Survey

Branch of Information Services

Box 25286

Federal Center

Denver, CO 80225 


\section{CONTENTS}

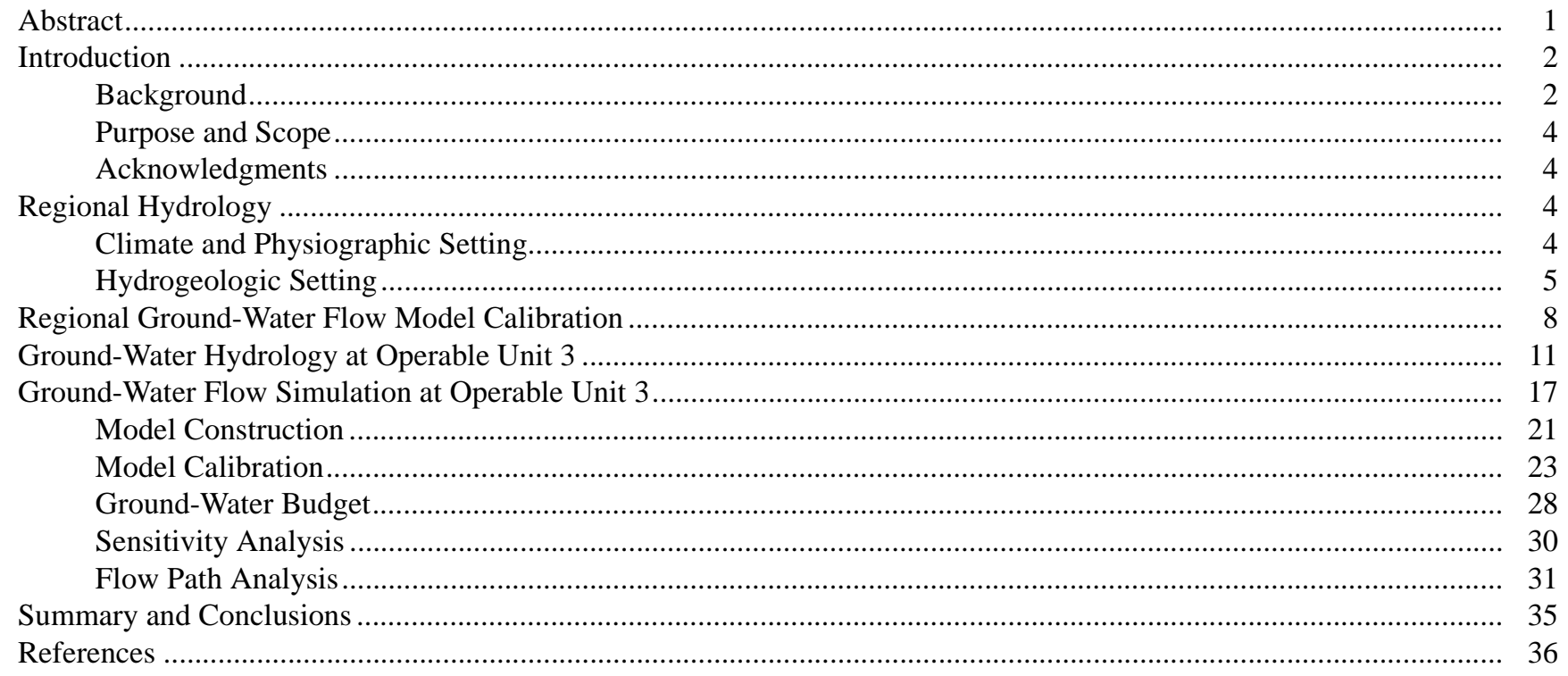

\section{Figures}

1. Map showing location of the Jacksonville Naval Air Station and regional study area ....................................... 3

2. Chart showing geologic units, hydrogeologic units, and equivalent layers used in the computer model.............. 5

3. Map showing potentiometric surface of the surficial aquifer on October 29 and 30, 1996, at the Jacksonville

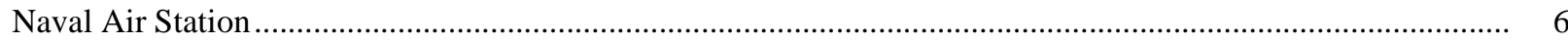

4. Ground-water fluctuations from May 1993 to March 1997 at the Jacksonville Naval Air Station ....................... 7

5. Net gain in streamflows for the period December 3, 1992, to October 30, 1996, at the Jacksonville Naval Air Station

6. Modifications to the regional ground-water flow model...

7. Particle pathlines representing simulated ground-water flow directions at the Jacksonville Naval Air Station..... 10

8. Comparison of measured and simulated heads for the regional model ............................................................. 11

9. Generalized hydrogeologic section through the subregional study area ....................................................... 11

10. Wells completed in the upper layer of the surficial aquifer within the subregional study area.......................... 12

11. Wells completed in the intermediate layer of the surficial aquifer within the subregional study area................... 12

12. Water table surface for the upper layer of the surficial aquifer on October 29 and 30, 1996, within the

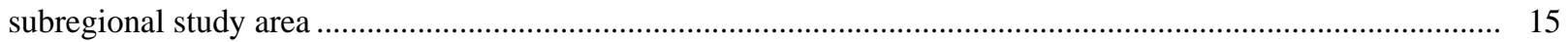

13. Stormwater drain system at the Jacksonville Naval Air Station .................................................................. 16

14. Map showing potentiometric surface for the intermediate layer of the surficial aquifer on October 29 and 30, 1996, within the subregional study area ............................................................................................ 16

15. Thickness of the clay layer that separates the upper and intermediate layers of the surficial aquifer .................. 18

16. Head differences between the intermediate and upper layers of the surficial aquifer......................................... 19

17. Generalized hydrologic section for the subregional model ............................................................................ 20

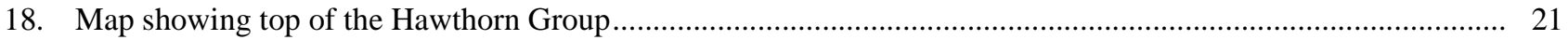

19. Location and orientation of the subregional model finite-difference grid............................................................ 22

20. Generalized hydrologic section for the subregional model ....................................................................... 23

21. Comparison of measured and simulated heads for the subregional model .................................................... 24

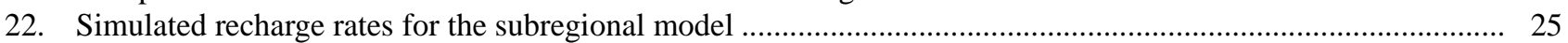

23. Simulated horizontal hydraulic conductivity of the upper layer of the subregional model .............................. 25 
24. Simulated vertical leakance between the upper and the intermediate layers of the subregional model ................. 26

25. Simulated transmissivity for the intermediate layer of the subregional model..................................................27

26. Simulated water table surface of the upper layer of the subregional model ..................................................... 27

27. Simulated potentiometric surface of the intermediate layer of the subregional model ..................................... 28

28. Measured and model-simulated head differences between the intermediate and upper layers of the subregional model

29. Particle pathlines representing ground-water flow directions in the upper layer of the surficial aquifer at Operable Unit 3 .....

30. Particle pathlines representing ground-water flow directions in the intermediate layer of the surficial aquifer at Operable Unit 3 ....

31. Generalized section showing particle pathlines at Operable Unit 3

\section{Tables}

1. Monitoring wells completed in the upper layer of the surficial aquifer and located in the subregional study area

2. Monitoring wells completed in the intermediate layer of the surficial aquifer and located in the subregional study area

3. Simulated ground-water inflows and outflows for the subregional model

4. Summary of sensitivity analyses for the subregional model.

\section{CONVERSION FACTORS, VERTICAL DATUM, ABBREVIATIONS, AND ACRONYMS}

\begin{tabular}{rll}
\hline Multiply & By & To obtain \\
\hline inch (in.) & 2.54 & centimeter \\
inch per year (in/yr) & 2.54 & centimeter per year \\
foot (ft) & 0.3048 & meter \\
foot per day & 0.3048 & meter per day \\
foot squared per day $\left(\mathrm{ft}^{2} / \mathrm{d}\right)$ & 0.09290 & meter squared per day \\
foot per year $(\mathrm{ft} / \mathrm{yr})$ & 0.3048 & meter per year \\
cubic foot per second $\left(\mathrm{ft}^{3} / \mathrm{s}\right)$ & 0.02832 & cubic meter per second \\
gallon $(\mathrm{gal})$ & 0.003785 & cubic meter \\
gallon $(\mathrm{gal})$ & .785 & liter \\
gallon per minute (gal/min) & 0.06309 & liter per second \\
million gallons per day (Mgal/d) & 0.04381 & cubic meter per second \\
gallon (gal) & 3.785 & liter \\
mile (mi) & 1.609 & kilometer \\
acre & 4,047 & square meter \\
\hline
\end{tabular}

Temperature in degrees Fahrenheit $\left({ }^{\circ} \mathrm{F}\right)$ may be converted to degrees Celsius $\left({ }^{\circ} \mathrm{C}\right)$ as follows:

$$
{ }^{\circ} \mathrm{C}=\left({ }^{\circ} \mathrm{F}-32\right) / 1.8
$$

Sea level: In this report, "sea level" refers to the National Geodetic Vertical Datum of 1929-- a geodetic datum derived from a general adjustment of the first-order level nets of both the United States and Canada, formerly called Sea Level Datum of 1929. 


\section{Acronyms}

ABB-ES ABB Environmental Services, Inc.

MODFLOW Modular Three-Dimensional Finite-Difference

Ground-Water Flow Model

OU1 Operable Unit 1

OU3 Operable Unit 3

Station Naval Air Station

USEPA U. S. Environmental Protection Agency

USGS U.S. Geological Survey 


\section{vi Contents}




\title{
Ground-Water Hydrology and Simulation of Ground- Water Flow at Operable Unit 3 and Surrounding Region, U.S. Naval Air Station, Jacksonville, Florida
}

\author{
By J. Hal Davis
}

\section{Abstract}

The Naval Air Station, Jacksonville (herein referred to as the Station,) occupies 3,800 acres adjacent to the St. Johns River in Duval County, Florida. Operable Unit 3 (OU3) occupies 134 acres on the eastern side of the Station and has been used for industrial and commercial purposes since World War II. Ground water contaminated by chlorinated organic compounds has been detected in the surficial aquifer at OU3. The U.S. Navy and U.S. Geological Survey (USGS) conducted a cooperative hydrologic study to evaluate the potential for ground water discharge to the neighboring St. Johns River. A groundwater flow model, previously developed for the area, was recalibrated for use in this study.

At the Station, the surficial aquifer is exposed at land surface and forms the uppermost permeable unit. The aquifer ranges in thickness from 30 to 100 feet and consists of unconsolidated silty sands interbedded with local beds of clay. The low-permeability clays of the Hawthorn Group form the base of the aquifer.

The USGS previously conducted a ground-water investigation at the Station that included the development and calibration of a 1-layer regional ground-water flow model. For this investigation, the regional model was recalibrated using additional data collected after the original calibration. The recalibrated model was then used to establish the boundaries for a smaller subregional model roughly centered on OU3.

Within the subregional model, the surficial aquifer is composed of distinct upper and intermediate layers. The upper layer extends from land surface to a depth of approximately 15 feet below sea level; the intermediate layer extends from the upper layer down to the top of the Hawthorn Group. In the northern and central parts of OU3, the upper and intermediate layers are separated by a low-permeability clay layer. Horizontal hydraulic conductivities in the upper layer, determined from aquifer tests, range from 0.19 to 3.8 feet per day. The horizontal hydraulic conductivity in the intermediate layer, determined from one aquifer test, is 20 feet per day.

An extensive stormwater drainage system is present at OU3 and the surrounding area. Some of the stormwater drains have been documented to be draining ground water from the upper layer of the surficial aquifer, whereas other drains are only suspected to be draining ground water.

The subregional model contained 78 rows and 148 columns of square model cells that were 100 feet on each side. Vertically, the surficial aquifer was divided into two layers; layer 1 represented the upper layer and layer 2 represented the intermediate layer. Steady-state ground-water flow conditions were assumed. The model was calibrated to head data collected on October 29 and 30, 1996. After calibration, the model matched all 67 measured heads to within the calibration criterion of 1 foot; and 48 of 67 simulated heads (72 percent) were within 0.5 foot. 
Model simulated recharge rates ranged from 0.4 inch per year in areas that were largely paved to 13.0 inches per year in irrigated areas. Simulated hydraulic conductivities in the upper layer at OU3 ranged from 0.5 foot per day in the north to 1.0 foot per day in the south. Simulated vertical leakance between the upper and intermediate layers ranged from $1.0 \times 10^{-6}$ per day in an area with low-permeability clays to $4.3 \times 10^{-2}$ per day in an area that had been dredged. Simulated transmissivities in the intermediate layer ranged from 25 feet squared per day in an area of low-permeability channel-fill deposits to a high of 1,200 feet squared per day in areas covering most of OU3. Simulated riverbed conductances ranged from 4 to 60 feet squared per day and simulated bottom conductances of leaking stormwater drains ranged from 5 to 20 feet squared per day.

The direction and velocity of ground-water flow was determined using particle-tracking techniques. Ground-water flow in the upper layer was generally eastward toward the St. Johns River. However, leaking stormwater drains locally modified the flow system to create small areas with flow that was diverted to the drains. The flow velocities in the upper layer at OU3 were slow, averaging about 2 feet per year. The slow velocities were primarily the result of the low horizontal hydraulic conductivity and, secondarily, the result of the low recharge rate. The simulated rate at which ground water leaked into the stormwater drains was low, averaging about 0.0011 cubic feet per second per 100 feet of stormwater drainage conduit. Ground-water flow in the intermediate layer moved eastward toward and discharged into the St. Johns River. Flow velocities were significantly higher in this layer than in the upper layer. The velocity was about 35 and 12 feet per year in the northern and southern parts of OU3, respectively.

\section{INTRODUCTION}

\section{Background}

The Naval Air Station, Jacksonville (herein referred to as the Station), occupies 3,800 acres adjacent to the St. Johns River in Jacksonville, Florida (fig. 1). The mission of the Station is to provide aerial anti-submarine warfare support, aviator training, and aircraft maintenance. Support facilities at the Station include an airfield, a maintenance depot, a Naval Hospital, a Naval Supply Center, a Navy Family Service Center, and recreational and residential facilities. Approximately 15,000 personnel are employed at the Station. Military activities have been conducted there since 1909.

The Station was placed on the U.S. Environmental Protection Agency's (USEPA) National Priorities List in December 1989 and is participating in the U.S. Department of Defense Installation Restoration Program, which serves to identify and remediate environmental contamination, in compliance with the Comprehensive Environmental Response, Compensation, and Liability Act and the Superfund Amendments and Reauthorization Act of 1980 and 1985, respectively. On October 23, 1990, the Station entered into a Federal Facility Agreement with the USEPA and the Florida Department of Environmental Protection which designated Operable Units 1, 2, and 3 within the Station to facilitate remedial response activities (U.S. Navy, 1994). Operable Units were designated in areas where several sources of similar contamination existed in close proximity. The purpose of such designation was to allow the contaminated areas to be addressed in one coordinated effort.

Operable Unit 3 (OU3) occupies 134 acres on the eastern side of the Station (fig. 1). The area encompassed by OU3 is currently used for industrial and commercial purposes. The principal tenant is the Naval Aviation Depot, where approximately 3,000 personnel are employed in servicing and refurbishing numerous types of military aircraft. Waste materials spilled or disposed of at OU3 in past years include paint sludges, solvents, battery acids, aviation fuels, petroleum lubricants, and radioactive materials (U.S. Navy, 1994). The ground water of the surficial aquifer underlying OU3 has been contaminated by chlorinated organic compounds (U.S. Navy, 1994). Current investigations indicate that ground-water contamination is restricted to nine isolated "hot spot" areas. In six of these areas, the contamination is present in the upper layer of the surficial aquifer; in three of these areas, the contamination is present in the intermediate layer. The terms upper layer and intermediate layer are used to conform with the terminology of ABB Environmental Services, Inc. (ABB-ES); the upper and intermediate layers comprise the full thickness of the surficial aquifer; there is no lower layer (U.S. Navy, 1994).

2 Ground-Water Hydrology and Simulation of Ground-Water Flow at Operable Unit 3 and Surrounding Region, U.S. Naval Air Station, Jacksonville, Florida 


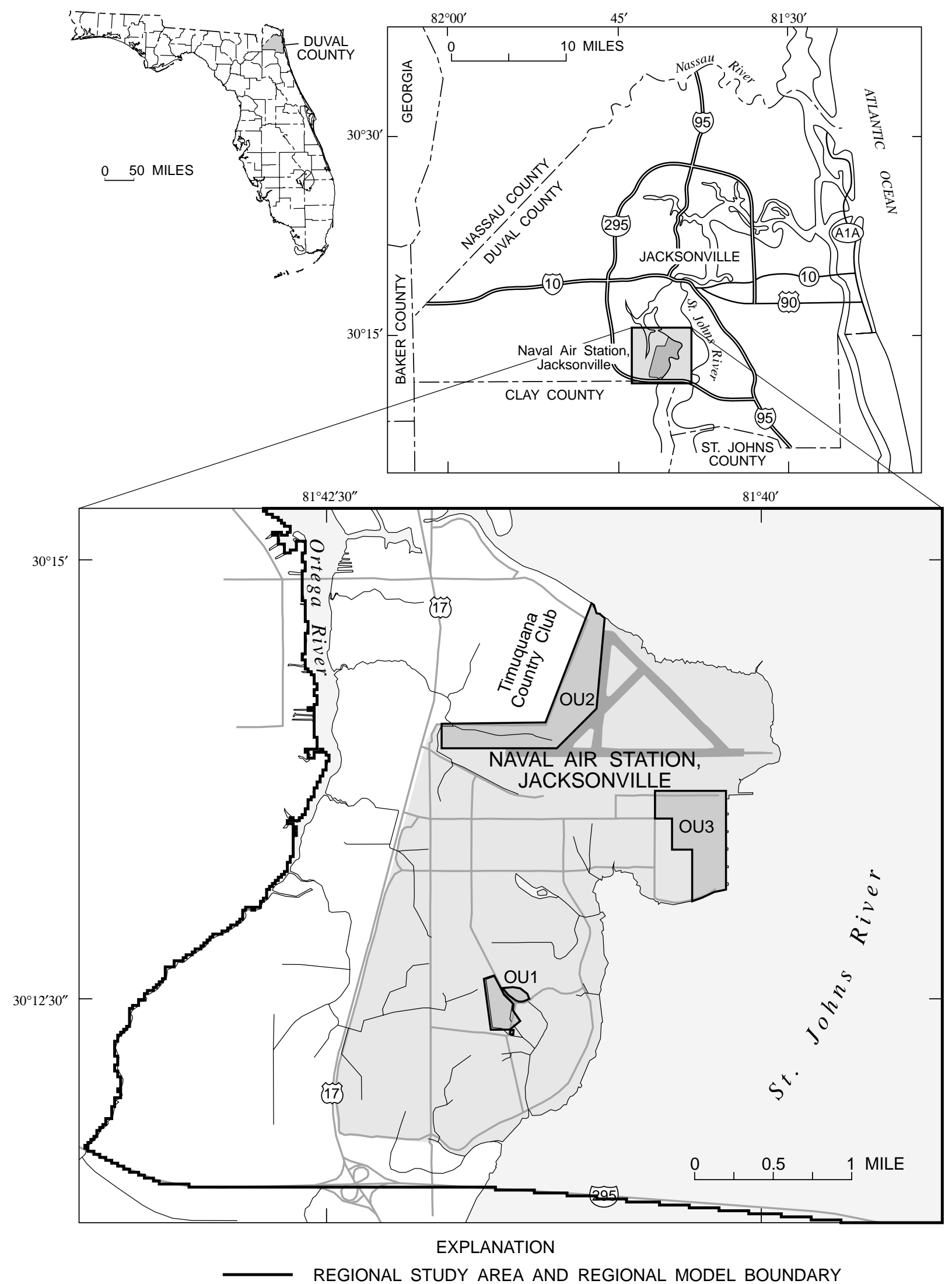

Figure 1. Location of the Jacksonville Naval Air Station and regional study area. 
The USGS began working with the Station in 1991 when Navy officials were concerned about the possible off-site migration of contaminated ground water at Operable Unit 1 (OU1) and vicinity. As part of that investigation, a regional ground-water flow model of the surficial aquifer at the Station and surrounding area was developed and calibrated. At the area of interest around OU1, the surficial aquifer is relatively thin (about $40 \mathrm{ft}$ ) and there are no significant head differences between the top and bottom of the aquifer; for this reason the aquifer was simulated using a 1-layer model. Directions and velocities of ground-water flow at OU1 and the Station were determined using the model. Additionally, the model was used to evaluate the effect on ground-water flow of proposed remedial designs at OU1. The modeling was documented in a report by Davis and others (1996).

Officials from Southern Division Naval Facilities Engineering Command are concerned about the potential for transport of organic compounds by ground water beneath OU3 to the adjacent St. Johns River. These officials requested that the U.S. Geological Survey numerically simulate ground-water flow in the surficial aquifer to determine directions, velocities, and ultimate discharge points of ground water. This ground-water modeling augmented the work of ABB-ES which was contracted by the Navy to delineate and document the extent of contamination, assess the risk to human health and environment, and, if required, design cleanup strategies. For a complete discussion of the occurrence of contamination at OU3 refer to U.S. Navy (1998).

\section{Purpose and Scope}

This report presents the results of a hydrologic investigation and computer modeling of ground-water flow at OU3 of the Naval Air Station, Jacksonville, Fla. The investigation, including data collection, was undertaken specifically to help evaluate the potential for off-site migration of contaminated ground water at OU3. The report describes the hydrology of the Station, recalibration of a regional 1-layer ground-water flow model using recently collected data, use of the recalibrated model to establish boundaries for a 2-layer subregional model of OU3, ground-water hydrology of the subregional model area, calibration of the subregional model, model simulation of ground-water flow at OU3, and the determination of ground-water velocities using flow path analysis.

\section{Acknowledgments}

The author expresses appreciation to Dana Gaskins, Cliff Casey, and Anthony Robinson of Southern Division Naval Facilities Engineering Command, Daine Lancaster of the Station; and Phylissa Miller, Willard Murry, Fred Bragdon, and Srinivas Kuchibotla of ABB Environmental Services, Inc.

\section{REGIONAL HYDROLOGY}

\section{Climate and Physiographic Setting}

The regional study area (fig. 1) encompasses the Station and vicinity. This area has a humid subtropical climate. The average annual rainfall and temperature in Jacksonville for 1967-96 was $60.63 \mathrm{in}$. and $78^{\circ} \mathrm{F}$, respectively, with most of the annual rainfall occurring in the late spring and early summer (Fairchild, 1972). The distribution of rainfall in the vicinity of Jacksonville is highly variable because the majority comes from scattered convective thunderstorms during the summer. Winters are mild and dry with occasional frost from November through February (Fairchild, 1972).

Land-surface topography consists of gently rolling hills. Elevations range from about $30 \mathrm{ft}$ above sea level at the tops of hills to $1 \mathrm{ft}$ above sea level at the shorelines of the St. Johns and Ortega Rivers. The Station is located in the Dinsmore Plain of the Northern Coastal Strip of the Sea Island District in the Atlantic Coastal Plain Section (Brooks, 1981). The Dinsmore Plain is characterized by low-relief clastic terrace deposits of Pleistocene to Holocene age (Brooks, 1981). 


\section{Hydrogeologic Setting}

The surficial aquifer is exposed at land surface and forms the uppermost permeable unit at the Station. The aquifer is composed of sedimentary deposits of Pliocene to Holocene age (fig. 2) and consists of 30 to $100 \mathrm{ft}$ of tan to yellow, medium- to fine-grained unconsolidated silty sands interbedded with lenses of clay, silty clay, and sandy clay (U.S. Navy, 1994). The Pleistocene-age sedimentary deposits in Florida were deposited in a series of terraces formed during marine transgressions and regressions associated with glacial and interglacial periods (Miller, 1986). The Station is underlain by the sediments of the Pamlico Terrace (Stringfield, 1966; Snell and Anderson, 1970; Healy, 1975). The Miocene age Hawthorn Group, composed mainly of low-permeability clays, underlies and forms the base of the surficial aquifer.

The surficial aquifer in Duval County is recharged by rainfall. The average recharge rate is estimated to be 10 to $16 \mathrm{in} \mathrm{/yr} \mathrm{(Fairchild,} \mathrm{1972).} \mathrm{Although} \mathrm{water} \mathrm{is} \mathrm{not} \mathrm{withdrawn} \mathrm{from} \mathrm{this} \mathrm{aquifer} \mathrm{for} \mathrm{potable} \mathrm{use} \mathrm{at} \mathrm{the} \mathrm{Station,}$ more than 50,000 domestic wells in Duval County pump approximately 8.7 Mgal/d from the aquifer. (Marella, 1993).

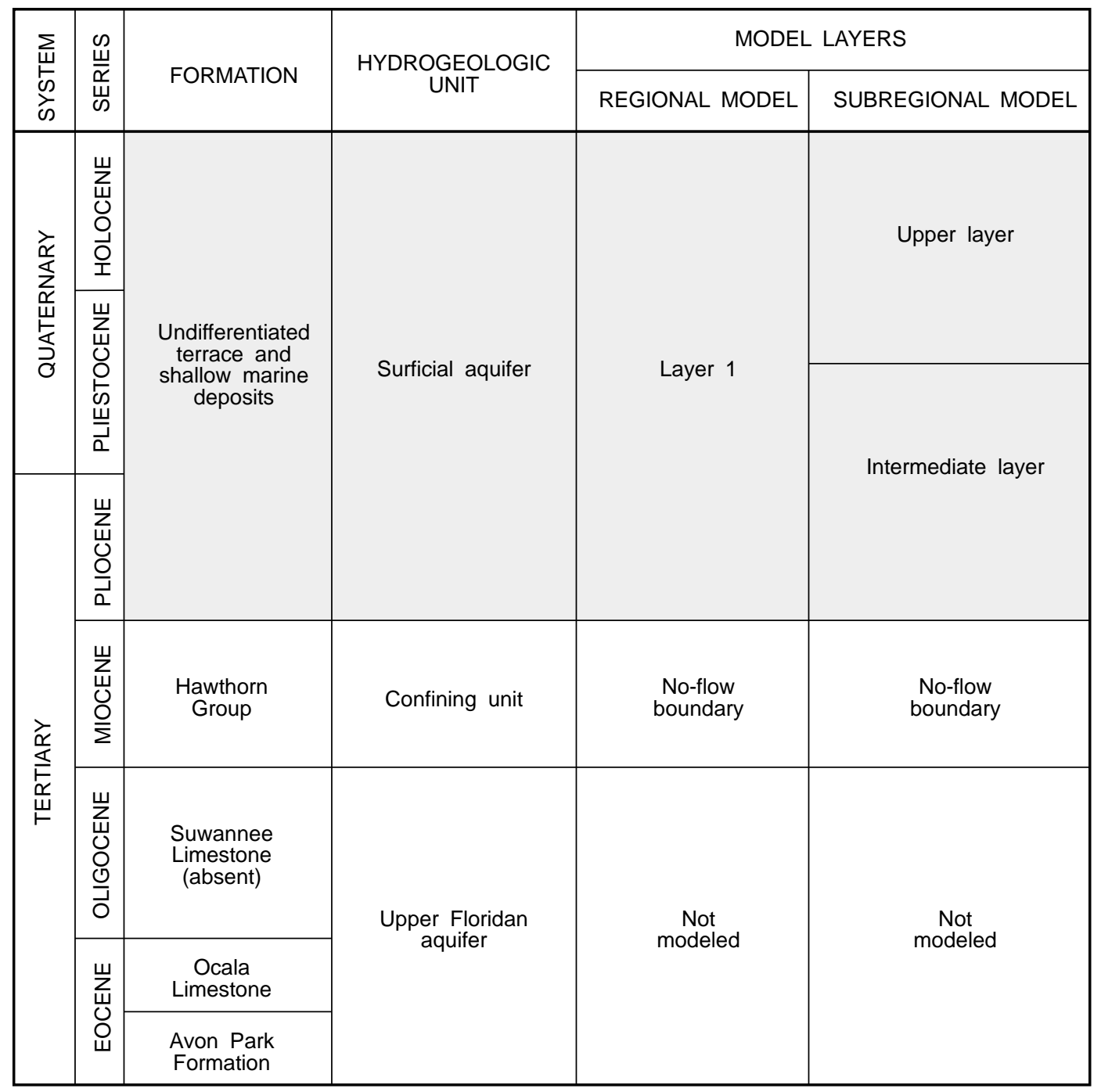

Figure 2. Geologic units, hydrogeologic units, and equivalent layers used in the computer model. 
The potentiometric surface of the surficial aquifer on October 29 and 30, 1996, is shown in figure 3. A northsouth trending ground-water high is present that runs through the center of the Station. Generally, east of the high, ground water flows toward the St. Johns River; west of the high, ground water flows toward the Ortega River. Ground water from the surficial aquifer discharges to these rivers and they form the natural hydrologic boundaries for the aquifer within the regional study area.

The heads in four wells for 1993-97 are shown in figure 4. The altitude of the heads show seasonal variation, but the annual mean water levels do not vary significantly from year to year. Davis and others (1996) reported that the surficial aquifer at the Station could be analyzed by assuming steady-state conditions; that is, there were no long-term changes in the altitude of the water table. The head data collected from these wells support this assumption.

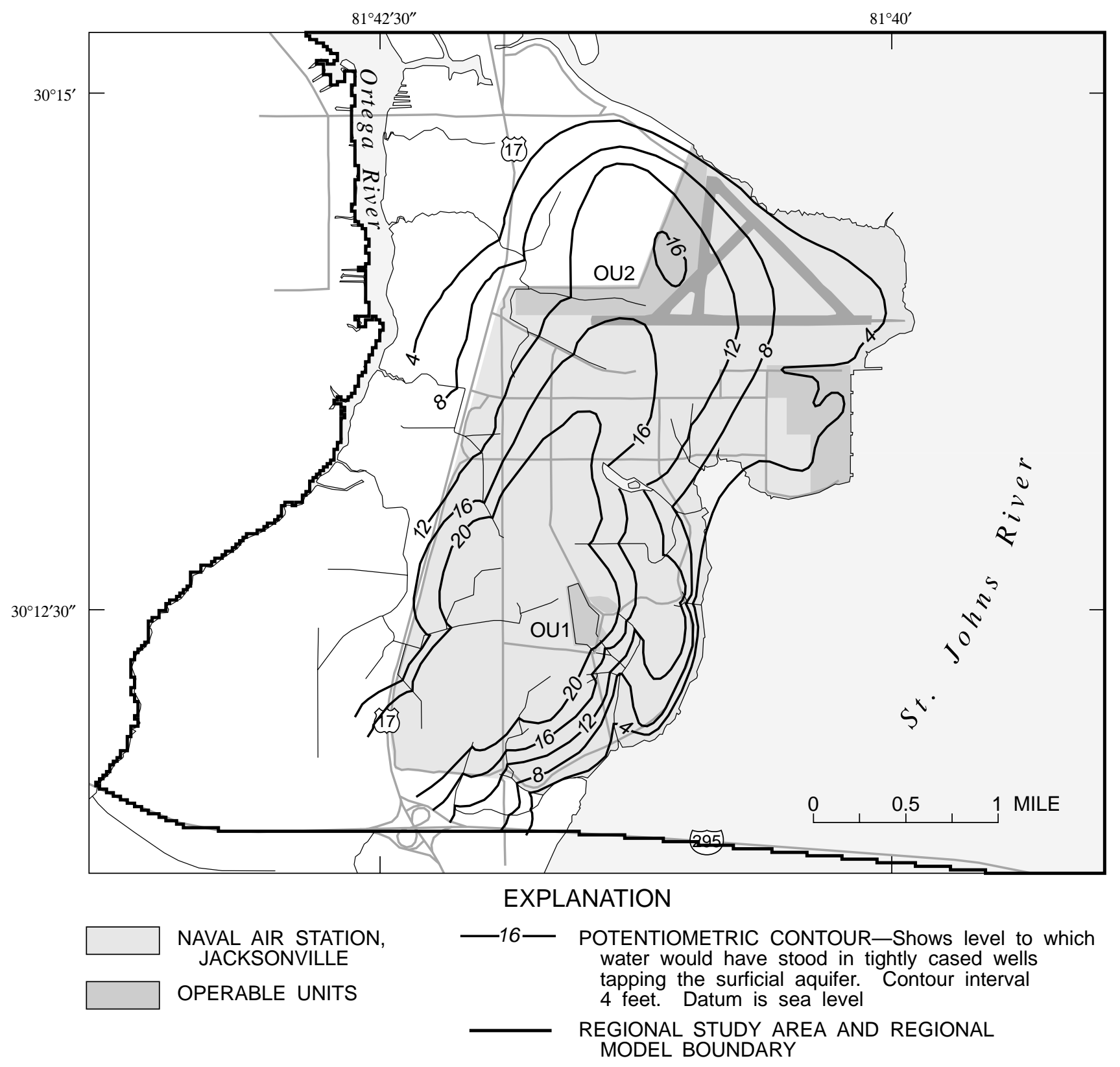

Figure 3. Potentiometric surface of the surficial aquifer on October 29 and 30, 1996, at the Jacksonville Naval Air Station. 

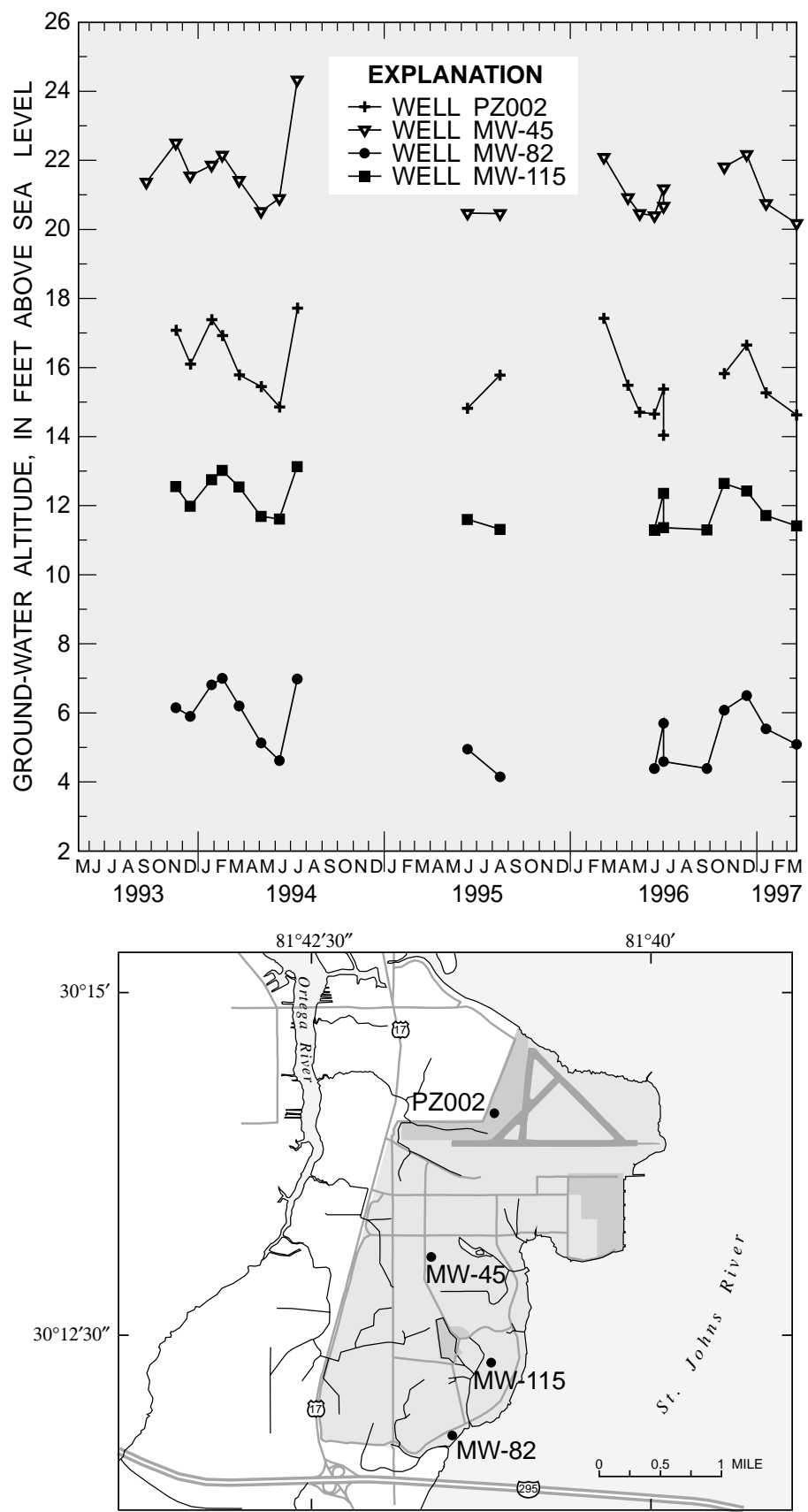

Figure 4. Ground-water fluctuations from May 1993 to March 1997 at the Jacksonville Naval Air Station.
Stream discharge measurements were taken on four separate occasions during periods when all streamflow was derived from groundwater seepage (fig. 5). The net gain in streamflows ranged from 0 to $0.39 \mathrm{ft}^{3} / \mathrm{s}$. Measurements taken on December 3, 1992, November 18, 1993, and October 29 and 30, 1996, show reasonable consistency. The difficulty in taking streamflow measurements contributed to variable values at individual sites. Factors that made the measurements difficult to take were: (1) shallow water that did not completely submerge the flowmeter, (2) submerged vegetation, and (3) low-flow velocities. The measurement error is not known exactly but probably ranged up to about 50 percent, especially for the very low streamflows. The May 15-16, 1996, measurements were consistently lower than the others due to the relatively higher evapotranspiration during the summer period preceding the measurements, whereas the other measurements were taken in the fall and winter when evapotranspiration is normally low.

The Hawthorn Group forms the base of the surficial aquifer and separates it from the underlying Upper Floridan aquifer. It is of Miocene age and unconformably overlies limestone of the Upper Floridan aquifer (Leve, 1978; Scott, 1988). The top of the Hawthorn Group ranges from 35 to $100 \mathrm{ft}$ below sea level at the Station, and is approximately $300 \mathrm{ft}$ thick. The Hawthorn Group is principally composed of dark gray and olive green sandy to silty clay, clayey sand, clay, and sandy limestone, all of which contain moderate to large amounts of black phosphatic sand, granules, or pebbles (Fairchild, 1972; Scott, 1988).

The Upper Floridan aquifer underlies the Hawthorn Group and is the source of public water supply in the vicinity of the Station. This aquifer consists of approximately $350 \mathrm{ft}$ of limestone and dolomite of the Ocala Limestone

and the Avon Park Formation, both of Eocene age (Miller, 1986). The top of the Avon Park Formation lies at approximately $600 \mathrm{ft}$ below sea level at the Station, and the top of the Ocala Group ranges from 300 to $400 \mathrm{ft}$ below sea level (Spechler, 1994). The Upper Floridan aquifer is recharged in the counties to the west where it is unconfined (Fairchild, 1977). Ground water in this aquifer generally flows eastward, where discharge occurs through wells, springs, and upward seepage into overlying formations (Fairchild, 1977; Bradner and others, 1992). Groundwater withdrawals from wells tapping this aquifer averaged approximately $144 \mathrm{Mgal} / \mathrm{d}$ in 1990 (Marella, 1993). The head in the Upper Floridan aquifer is approximately $15 \mathrm{ft}$ higher than the head in the surficial aquifer at the Station, creating an upward ground-water gradient between the Upper Floridan aquifer and the surficial aquifer. 


\section{REGIONAL GROUND-WATER FLOW MODEL CALIBRATION}

The USGS previously developed and calibrated a 1-layer ground-water flow model that simulated steadystate flow in the surficial aquifer within the regional study area. This model was calibrated to water- level and streamflow data collected on November 18, 1993. Simulations were made using the USGS Modular Three-Dimensional Finite-Difference Ground-Water Flow Model (MODFLOW) as described in McDonald and Harbaugh (1988). This regional model was recalibrated for this study to incorporate additional water-level data collected since that date. This section describes changes made to recalibrate the regional model which was then used to establish the boundaries for the subregional model at OU3.

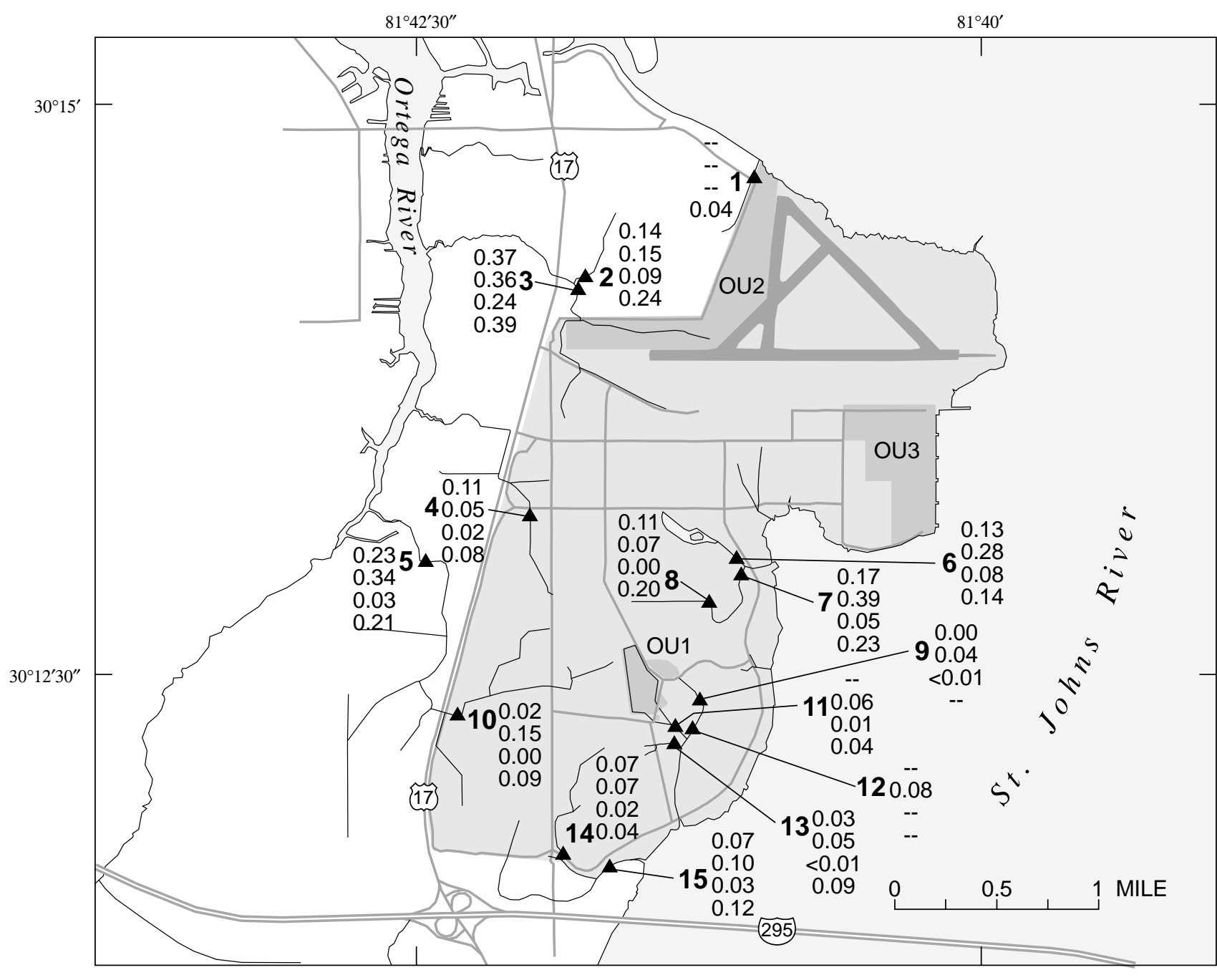

\section{EXPLANATION}

NAVAL AIR STATION, JACKSONVILLE

0.07

150.10 STREAMFLOW MEASUREMENT SITE AND NUMBER-Bold number is site number, values 0.03 (from top to bottom) are net gain in creek for December 3, 1992, November 18, 1993,

0.12 May 15-16, 1996, and October 29-30, 1996. Values in cubic feet per second

NOTE: "--" indicates no measurement taken

Figure 5. Net gain in streamflows for the period December 3, 1992, to October 30, 1996, at the Jacksonville Naval Air Station. 
The current data came from two shallow monitoring wells installed to provide water-level information in areas where data were sparse. After installation of these two wells, water levels were measured in all Station wells on October 29 and 30, 1996, concurrent with streamflow measurements. These data were then used to check the regional model calibration. Simulated heads of the regional model matched 128 of 131 measured heads from the updated data set to within the calibration criterion of $2.5 \mathrm{ft}$. The model did not match the head in the two new wells and in one of the original wells. To improve the match between the remaining three heads, adjustments were made to parameters of the original regional model.

For well A in figure 6, the original model overestimated the measured head by about $3.5 \mathrm{ft}$. To lower the simulated head in this area, a 0.5 -mi-long drain was added to the model and the recharge rate was lowered from 5 to $2.5 \mathrm{in} / \mathrm{yr}$. The drain represents a stormwater drain that is located beneath the airfield. The drain was field checked during a no-rainfall period and was draining a small volume of water. For well B, the original model underestimated the measured head by about $3.5 \mathrm{ft}$. To raise the simulated head in this area, the riverbed conductance of two small

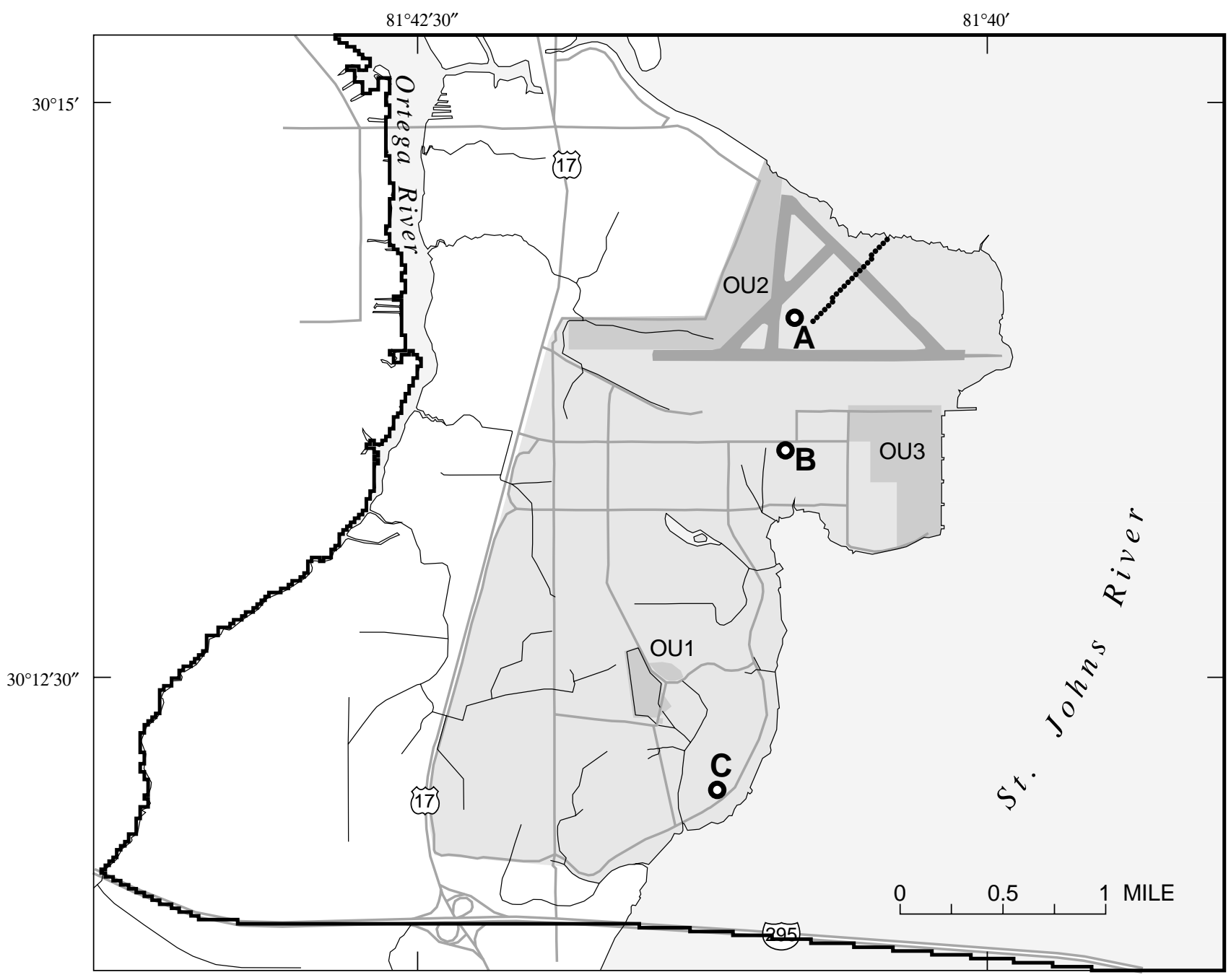

\section{EXPLANATION}

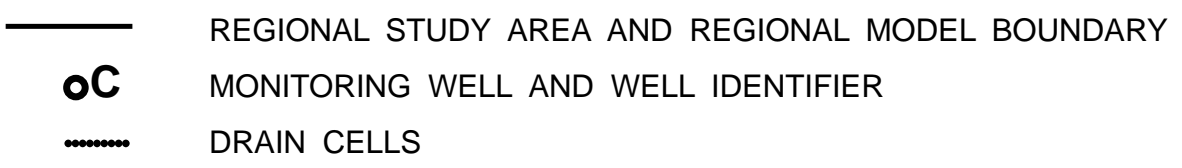

Figure 6. Modifications to the regional ground-water flow model. 
ditches that were simulated southwest of the well was reduced from 250 to $4 \mathrm{ft}^{2} / \mathrm{d}$ to represent the concrete liner that was installed in these ditches during World War II. The concrete liner limits ground-water seepage into the ditch. For well $\mathrm{C}$ in figure 6, both the initial and the final regional models overestimated the measured head by about $5.6 \mathrm{ft}$. A field check of the well indicated that the measured head was valid. Several unsuccessful attempts were made to improve the simulated head. The mismatch, however, should not affect computed heads at OU3 because well $\mathrm{C}$ is located at a relatively large distance away and is separated from OU3 by a lobe of the St. Johns River. Using the recalibrated regional model, the direction and velocity of ground-water flow (fig. 7) were calculated using MODPATH (Pollock, 1989).

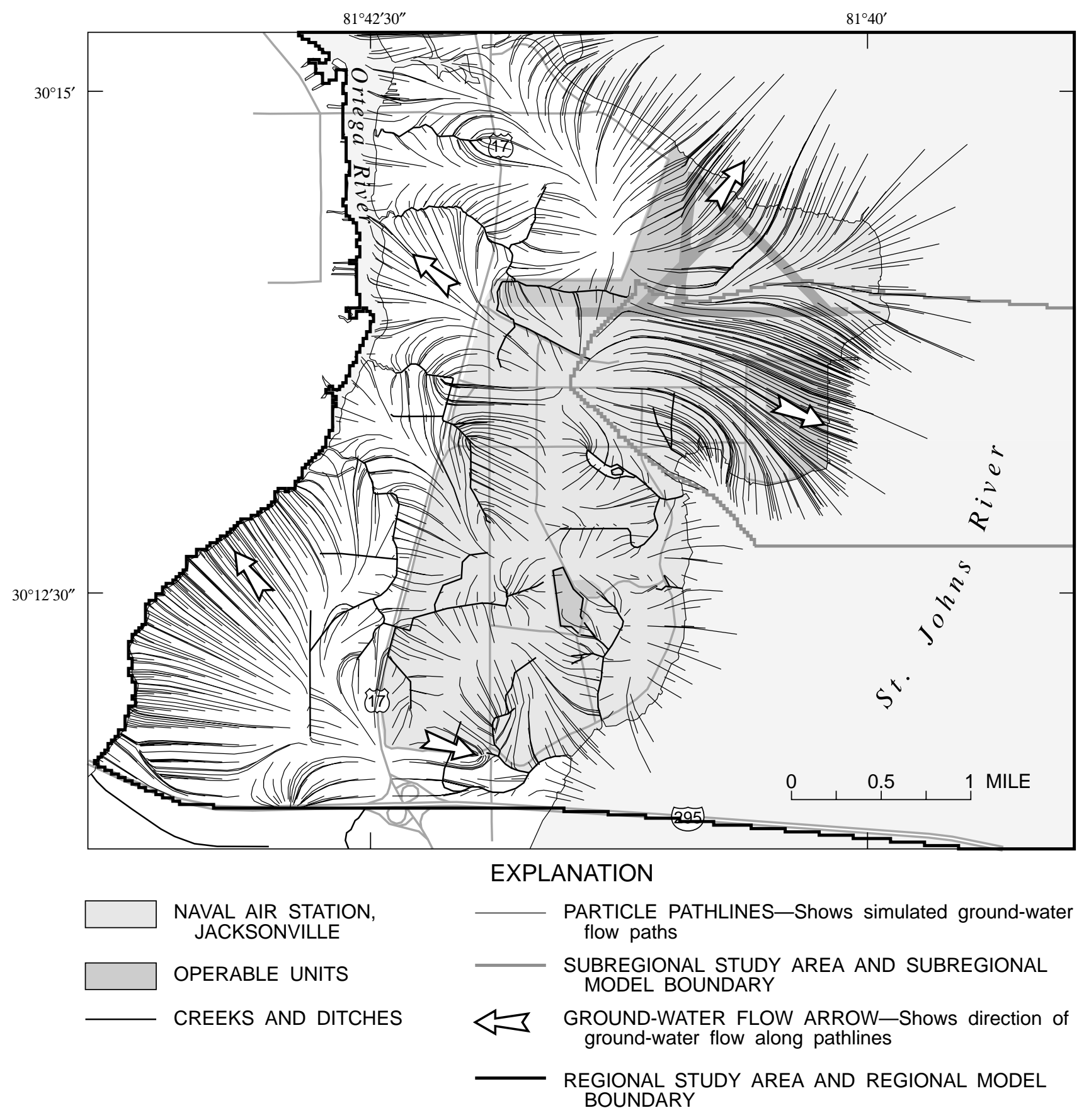

Figure 7. Particle pathlines representing simulated ground-water flow directions at the Jacksonville Naval Air Station. 


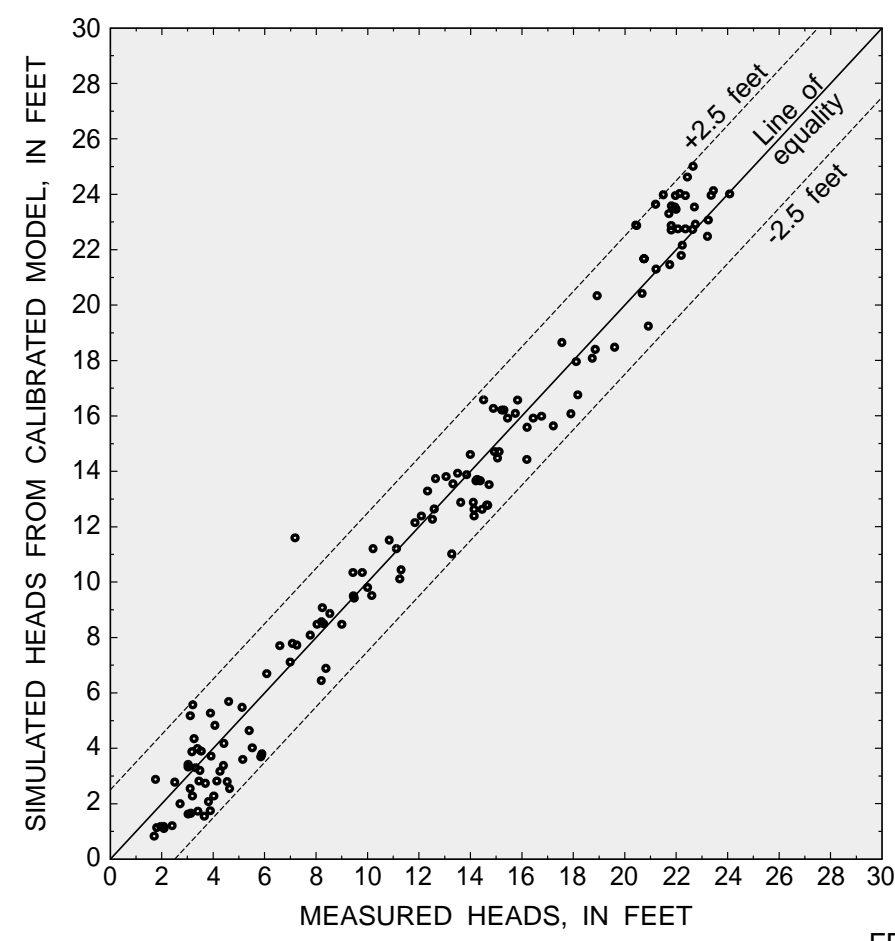

Figure 8. Comparison of measured and simulated heads for the regional model.

Figure 9. Generalized hydrogeologic section through the subregional study area.
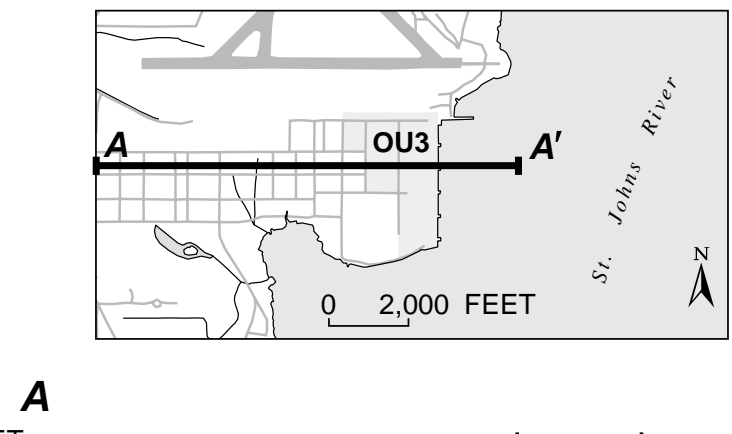

During calibration of the OU3 subregional model (discussed in a later section), the recharge rate within the subregional area was increased from the regional model values. The increased recharge was also applied to the regional model during recalibration to ensure consistency between the two models. When the recalibration of the regional model was completed, the simulated heads matched the measured heads within the calibration criterion of $2.5 \mathrm{ft}$ in 130 of 131 wells. A comparison of the measured and simulated heads for the final regional model is shown in figure 8.

Streamflows measured on November 18, 1993, for the original calibration, totaled $2.07 \mathrm{ft}^{3} / \mathrm{s}$. Streamflows measured on October 29 and 30, 1996, for the recalibrated model, totaled $1.87 \mathrm{ft}^{3} / \mathrm{s}$, a reduction of 10 percent. Streamflows were only totaled at sites where measurements were made over both periods. The streamflows were higher at six locations on October 29 and 30, 1996, than on November 18, 1996. Due to the similarity of streamflows during the two periods, the simulated recharge rate was not modified except where already discussed.
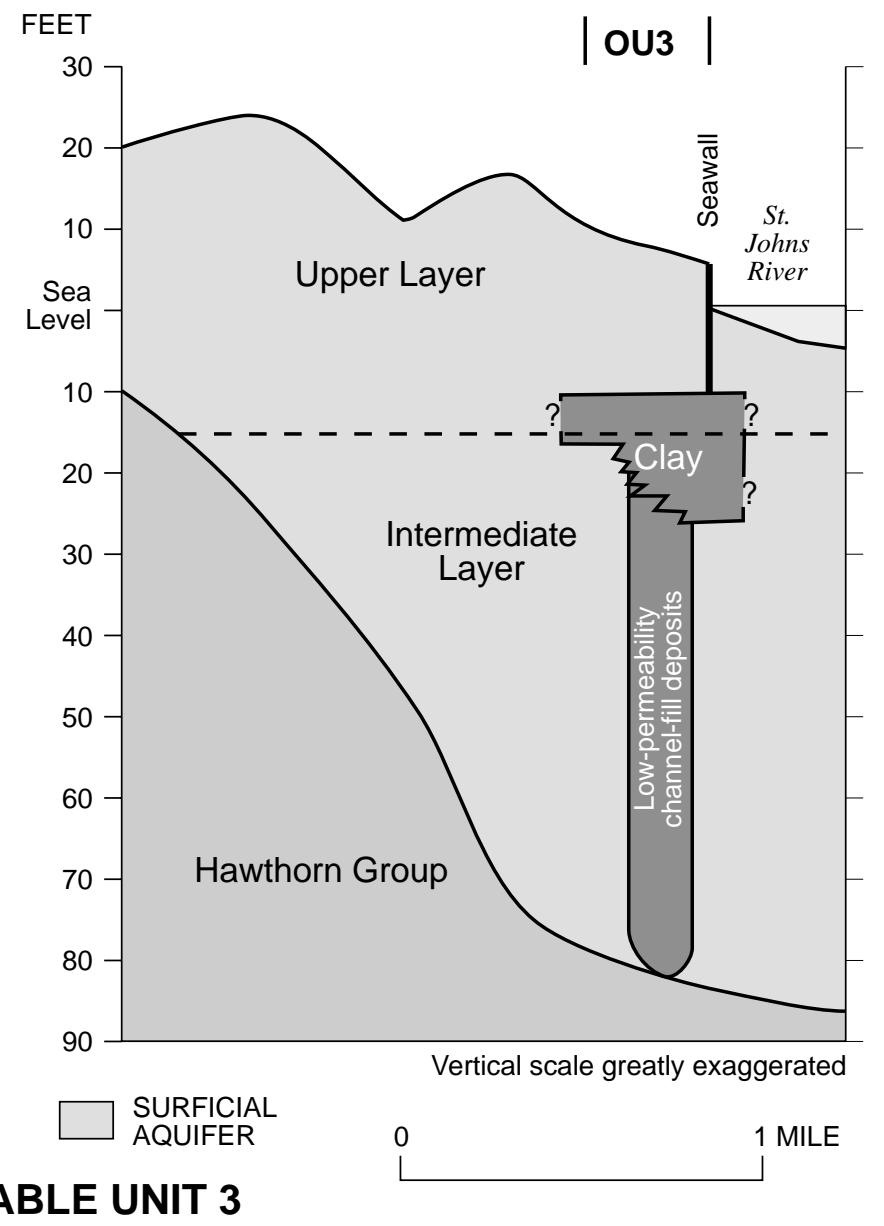

\section{GROUND-WATER HYDROLOGY AT OPERABLE UNIT 3}

The subregional study area encompasses OU3 and the nearby surrounding area (fig. 7). Within the subregional study area, the surficial aquifer is composed of two distinct layers (fig. 9). The upper layer is unconfined and extends from land surface to a depth of approximately $15 \mathrm{ft}$ below sea level; the intermediate layer is confined and 
extends from the upper layer downward to the top of the Hawthorn Group. In the northern and central parts of OU3, the upper and intermediate layers are separated by a very low-permeability clay layer. The upper and intermediate layers span the full thickness of the surficial aquifer. The locations of monitoring wells installed in the upper and intermediate layers are shown in figures 10 and 11, respectively; the wells are described in tables 1 and 2.

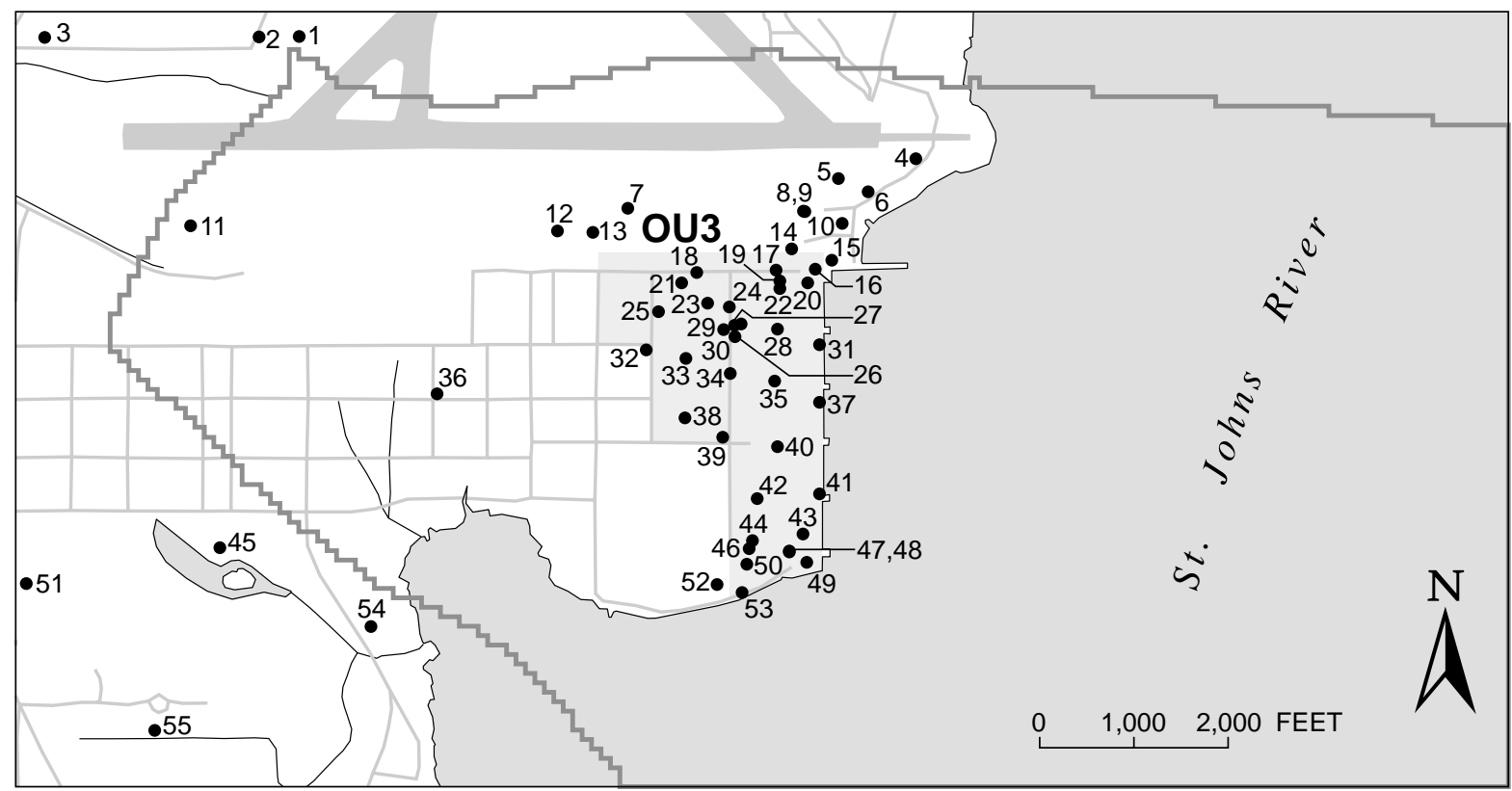

EXPLANATION

OU3 SUBREGIONAL STUDY AREA AND SUBREGIONAL MODEL BOUNDARY

-55 UPPER LAYER WELL WITH NUMBER-Number corresponds to map number in table 1

Figure 10. Wells completed in the upper layer of the surficial aquifer within the subregional study area.

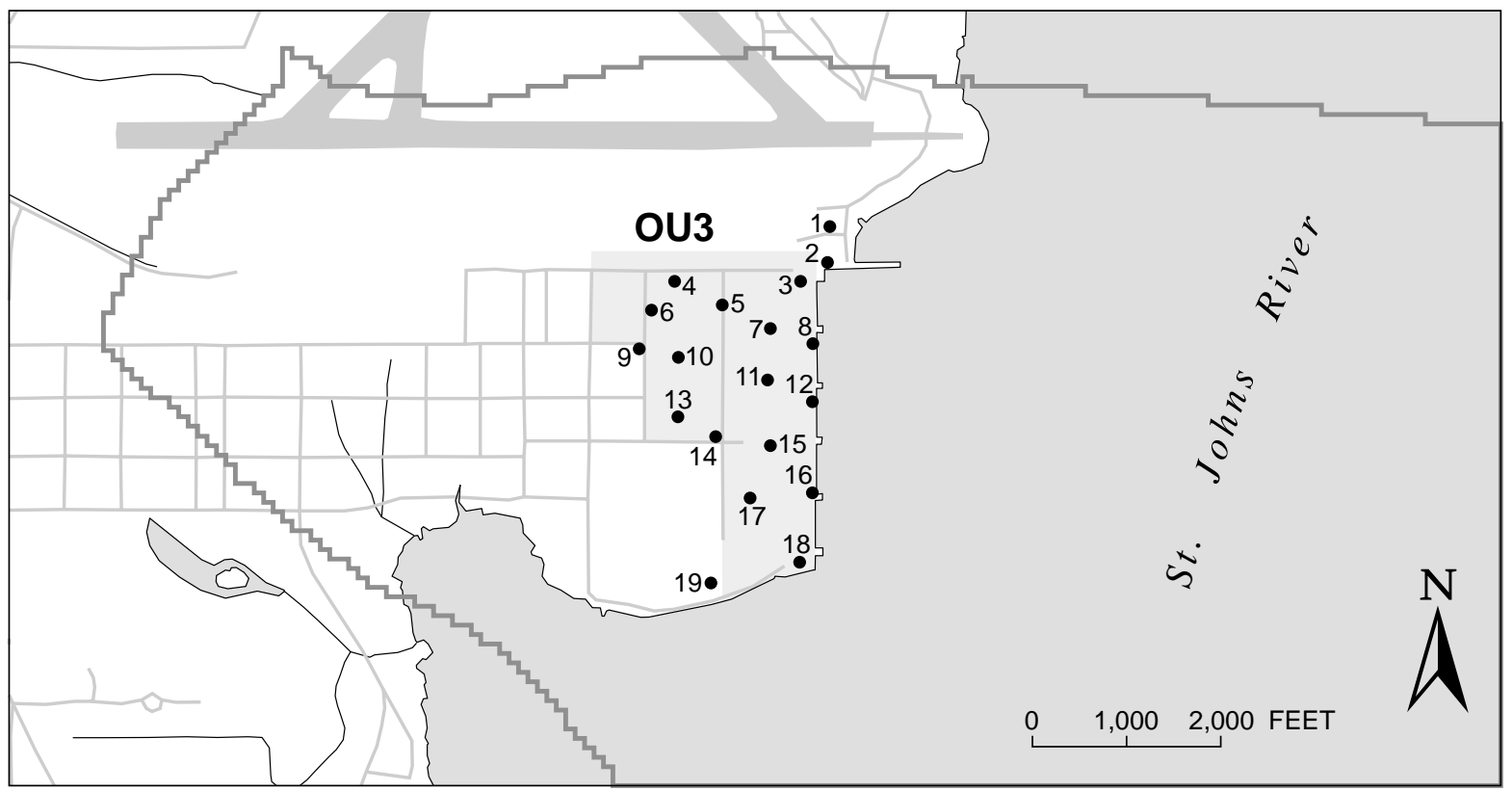

\section{EXPLANATION}

\section{OU3 SUBREGIONAL STUDY AREA AND SUBREGIONAL MODEL BOUNDARY}

19• INTERMEDIATE LAYER WELL WITH NUMBER-Number corresponds to map number in table 2

Figure 11. Wells completed in the intermediate layer of the surficial aquifer within the subregional study area. 
Table 1. Monitoring wells completed in the upper layer of the surficial aquifer and located in the subregional study area

[---, Shallow well, exact depth is unknown]

\begin{tabular}{|c|c|c|c|c|}
\hline Map number & Well name & $\begin{array}{l}\text { Altitude of top } \\
\text { of casing, } \\
\text { in feet }\end{array}$ & $\begin{array}{l}\text { Well depth, } \\
\text { in feet }\end{array}$ & $\begin{array}{c}\text { Altitude of head on } \\
\text { October } 29 \text { and } 30 \text {, } \\
1996 \text {, in feet }\end{array}$ \\
\hline 1 & MW-16 & 20.68 & 12.0 & 14.89 \\
\hline 2 & U2PZ001 & 19.15 & --- & 14.51 \\
\hline 3 & U2PZ006 & 19.13 & --- & 12.33 \\
\hline 4 & JAX-TF-MW27 & 6.20 & 9.0 & 4.02 \\
\hline 5 & JAX-TF-MW24 & 7.59 & 7.0 & 4.39 \\
\hline 6 & JAX-TF-MW37 & 5.73 & 7.0 & 3.69 \\
\hline 7 & JAX-HA-MW03 & 10.04 & 12.0 & 6.99 \\
\hline 8 & JAX-TF-MW41 & 10.29 & 12.0 & 5.89 \\
\hline 9 & JAX-TF-MW47D & 10.17 & 25.6 & 5.85 \\
\hline 10 & JAX-TF-MW14 & 8.65 & 11.0 & 4.14 \\
\hline 11 & MW41-R & 21.29 & --- & 17.55 \\
\hline 12 & JAX-HA-MW05 & 11.11 & 12.0 & 8.21 \\
\hline 13 & JAX-HA-MW06 & 10.23 & 12.0 & 7.25 \\
\hline 14 & NARF-17 & 12.15 & 17.4 & 5.15 \\
\hline 15 & JAX-TF-MW06 & 8.33 & 11.0 & 4.63 \\
\hline 16 & NARF-18 & 8.12 & 15.5 & 1.75 \\
\hline 17 & NARF-16 & 9.04 & 14.4 & 3.91 \\
\hline 18 & NARF-15 & 10.76 & 17.5 & 3.89 \\
\hline 19 & U3P159MW-2 & 7.61 & 13.3 & 3.02 \\
\hline 20 & U3P159MW-1 & 6.56 & 13.5 & 2.50 \\
\hline 21 & PZ024 & 9.04 & 14.0 & 3.20 \\
\hline 22 & U3P159MW-3 & 8.32 & 12.9 & 3.02 \\
\hline 23 & U3B101MW-3 & 9.71 & 13.5 & 4.06 \\
\hline 24 & NARF-14 & 9.04 & 15.0 & 3.25 \\
\hline 25 & ТР008 & 9.70 & 18.2 & 4.60 \\
\hline 26 & U3P159MW-4 & 8.22 & 13.0 & 3.17 \\
\hline 27 & MW-6 & 8.49 & 14.1 & 3.38 \\
\hline 28 & PZ014 & 8.50 & 14.0 & 3.48 \\
\hline 29 & U3B101MW-4 & 9.88 & 13.4 & 4.41 \\
\hline 30 & MW-7 & 8.72 & 11.4 & 3.53 \\
\hline 31 & PZ004 & 5.64 & 14.0 & 2.71 \\
\hline 32 & PZ026 & 10.86 & 13.5 & 5.12 \\
\hline 33 & MW-1 & 9.99 & 13.0 & 5.40 \\
\hline 34 & PZ019 & 9.15 & 14.0 & 3.70 \\
\hline 35 & PZ006 & 8.19 & 14.5 & 4.54 \\
\hline 36 & MW-122 & 13.67 & 13.5 & 10.00 \\
\hline 37 & PZ010 & 5.90 & 14.0 & 3.13 \\
\hline 38 & PZ021 & 9.99 & 13.0 & 5.52 \\
\hline 39 & PZ017 & 10.77 & 14.0 & 4.26 \\
\hline 40 & PZ012 & 9.22 & 15.0 & 3.19 \\
\hline 41 & PZ001 & 3.99 & 13.0 & 1.96 \\
\hline 42 & PZ008 & 9.40 & 16.0 & 3.81 \\
\hline 43 & JAX873-6 & 7.34 & 12.6 & 1.80 \\
\hline 44 & NARF-B1 & 11.65 & 16.5 & 3.40 \\
\hline 45 & MW-47 & 20.99 & 14.5 & 15.05 \\
\hline 46 & NARF-9 & 18.39 & 27.5 & 3.88 \\
\hline 47 & JAX873-4 & 8.16 & 13.1 & 2.07 \\
\hline
\end{tabular}


Table 1. Monitoring wells completed in the upper layer of the surficial aquifer and located in the subregional study area--Continued

[---, Shallow well, exact depth is unknown]

\begin{tabular}{clccc}
\hline Map number & Well name & $\begin{array}{c}\text { Altitude of top } \\
\text { of casing, } \\
\text { in feet }\end{array}$ & $\begin{array}{c}\text { Well depth, } \\
\text { in feet }\end{array}$ & $\begin{array}{c}\text { Altitude of head on } \\
\text { October 29 and 30, } \\
\text { 1996, in feet }\end{array}$ \\
\hline 48 & JAX873-5 & 8.14 & 25.1 & 2.08 \\
49 & JAX873-10 & 6.79 & 12.5 & 1.70 \\
50 & NARF-11 & 19.28 & 27.8 & 3.65 \\
51 & MW-45 & 27.45 & 16.0 & 21.81 \\
52 & MW-49 & 22.11 & 25.5 & 3.02 \\
53 & NARF-12 & 6.01 & 17.5 & 2.40 \\
54 & MW-121 & 11.47 & 13.5 & 8.20 \\
55 & MW-52 & 27.76 & 16.0 & 18.92 \\
\hline
\end{tabular}

Table 2. Monitoring wells completed in the intermediate layer of the surficial aquifer and located in the subregional study area.

\begin{tabular}{clccc}
\hline Map number & Well name & $\begin{array}{c}\text { Altitude of top } \\
\text { of casing, } \\
\text { in feet }\end{array}$ & $\begin{array}{c}\text { Well depth, } \\
\text { in feet }\end{array}$ & $\begin{array}{c}\text { Altitude of head on } \\
\text { October 29 and 30, } \\
\text { 1996, in feet }\end{array}$ \\
\hline 1 & JAX-TF-MW49D & 8.23 & 33.0 & 3.44 \\
2 & JAX-TF-MW48D & 8.36 & 36.5 & 3.10 \\
3 & PZ027 & 6.68 & 88.5 & 3.53 \\
4 & PZ023 & 9.23 & 80.50 & 5.60 \\
5 & NARF-D1 & 8.84 & 55.3 & 6.44 \\
6 & PZ030 & 9.52 & 79.3 & 5.13 \\
7 & PZ013 & 8.65 & 67.5 & 4.81 \\
8 & PZ003 & 5.71 & 63.7 & 6.21 \\
9 & PZ025 & 10.69 & 85.5 & 3.40 \\
10 & PZ022 & 10.14 & 82.5 & 3.39 \\
11 & PZ005 & 8.24 & 99.0 & 4.30 \\
12 & PZ009 & 5.90 & 94.0 & 4.03 \\
13 & PZ020 & 10.04 & 89.5 & 3.45 \\
14 & PZ016 & 10.80 & 54.0 & 3.17 \\
15 & PZ011 & 9.27 & 93.0 & 3.77 \\
16 & PZ002 & 4.18 & 87.5 & 2.34 \\
17 & PZ007 & 9.62 & 61.0 & 3.26 \\
18 & PZ015 & 9.44 & 56.5 & 92.0 \\
19 & MW-50 & 21.96 & 9.5 & \\
\hline
\end{tabular}

Water-table contours indicate that ground-water flow in the upper layer moves generally eastward toward the St. Johns River (fig. 12). A seawall partially blocks ground-water flow in the upper layer along the central and northern parts of OU3. In this area, the seawall extends downward approximately $20 \mathrm{ft}$ deep and into the clay layer that separates the upper and intermediate layers. At the southern end of OU3, the seawall is set less than $20 \mathrm{ft}$ deep and the clay layer is much less continuous; lower heads in this area indicate that ground water is seeping under or through the seawall.

An extensive stormwater drainage system is present within the subregional study area (fig. 13). Groundwater seepage into the drains through joints and cracks has been documented by camera surveys in selected drains. Visual inspection of the drains by Navy personnel indicates that leaking joints and cracks are generally confined to high-traffic areas; within the high-traffic areas, approximately 30 percent of the joints leak. Depressions in the water-table surface caused by the drains could be observed in areas where the monitoring well density is high. The depths to the bottom of the drains vary but generally range from 5 to $10 \mathrm{ft}$ below land surface. The bottom and stage in the drains is below the water table, so the drains can remove ground water from the upper layer of the aquifer but cannot act as a source of water to the aquifer. 
Stormwater drains that are most likely to be leaking are shown on figure 13. Drains were determined to have a high potential to leak if (1) camera surveys showed them to be leaking, (2) they underlay high-traffic areas and a visual inspection showed flowing water in the drain during a no-rainfall period, or (3) depressions in the water-table surface indicated leakage. The presence of flowing water in a drain was not considered proof in itself that the drain was leaking, because there are other sources of water to the drains, such as condensate from sumps and air conditioners. However, a dry drain was considered proof of no ground-water leakage.

The horizontal hydraulic conductivity in the upper layer of the surficial aquifer at OU3 ranged from 0.19 to $3.8 \mathrm{ft} / \mathrm{d}$, with a mean value of $0.9 \mathrm{ft} / \mathrm{d}$, based on slug tests of seven piezometers (Geraghty and Miller, 1991). These values are within the range for silty sands described by Freeze and Cherry (1979). A horizontal hydraulic conductivity of $0.6 \mathrm{ft} / \mathrm{d}$ for the upper layer (U.S. Geological Survey data, 1997) was determined from a multiple-well aquifer test (location shown on fig. 12).

The potentiometric surface of the intermediate layer indicates that ground-water flow is generally eastward toward the St. Johns River (fig. 14). The eastward movement of ground water is partially blocked by a naturally occurring, nearly vertical wall of low-permeability channel-fill deposits (figs. 9 and 14) resulting in a sharp drop in the potentiometric surface from north to south. North of the channel-fill deposits, the horizontal ground-water gradient is significantly larger than south of the deposits. These channel-fill deposits extend from the top of the intermediate layer to the bottom or very near the bottom. U.S. Geological Survey topographic maps, made prior to construction at the Station, show that a deeply incised creek or inlet was present at the same location the channelfill deposits exist in the subsurface. These deposits could be the result of infilling of an erosional channel by lowpermeability sediments.

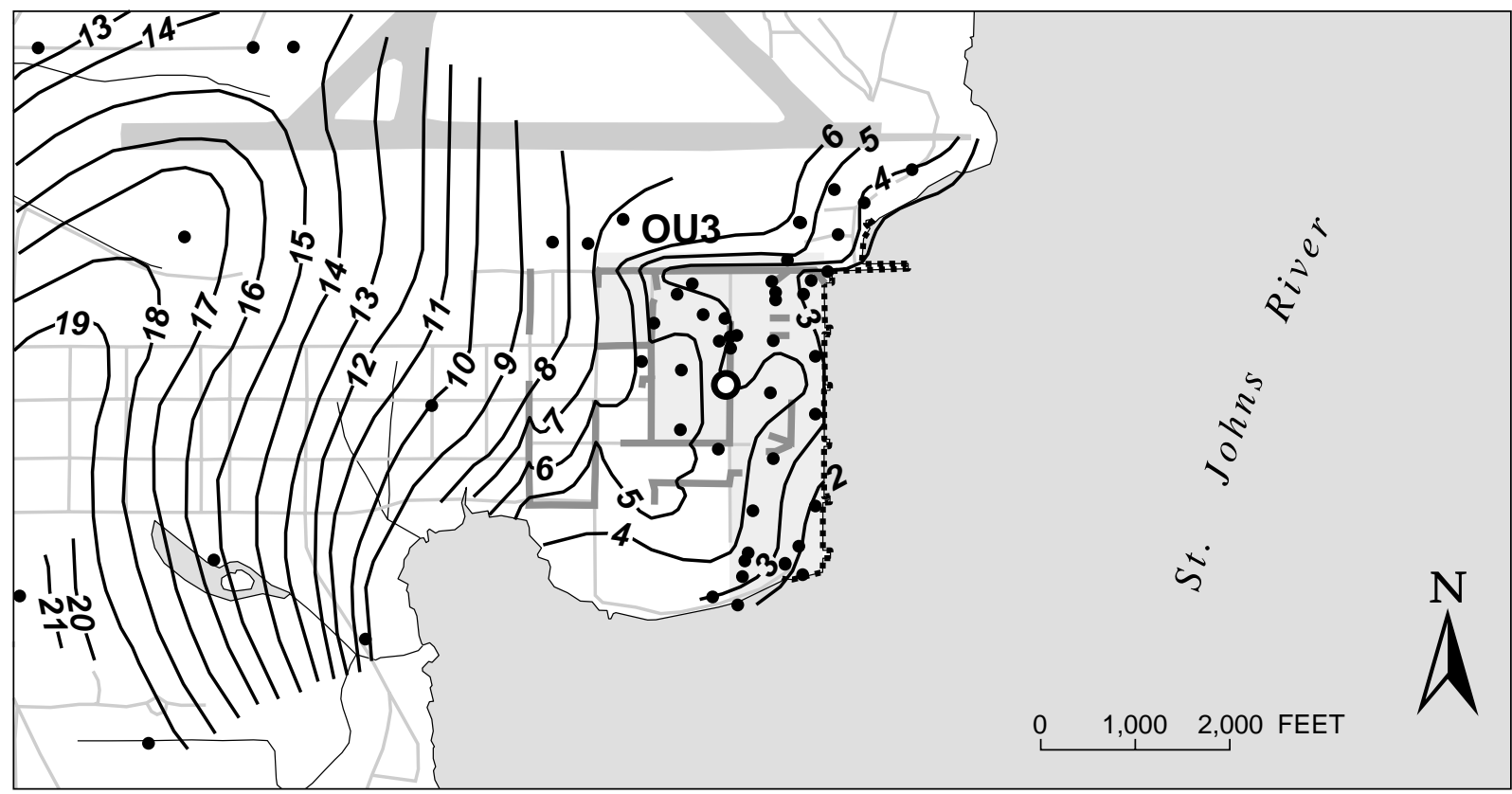

EXPLANATION

-19- WATER TABLE CONTOUR - Shows level to which water would have stood in tightly cased wells tapping the upper layer of the surficial aquifer. Contour interval 1 foot. Datum is sea level

STORMWATER DRAINS THAT MAY BE DRAINING GROUND WATER FROM THE UPPER LAYER OF THE SURFICIAL AQUIFER

SEAWALL

- MONITORING WELL LOCATION

- AQUIFER TEST LOCATION-Test conducted in the upper layer

Figure 12. Water table surface for the upper layer of the surficial aquifer on October 29 and 30, 1996, within the subregional study area. 


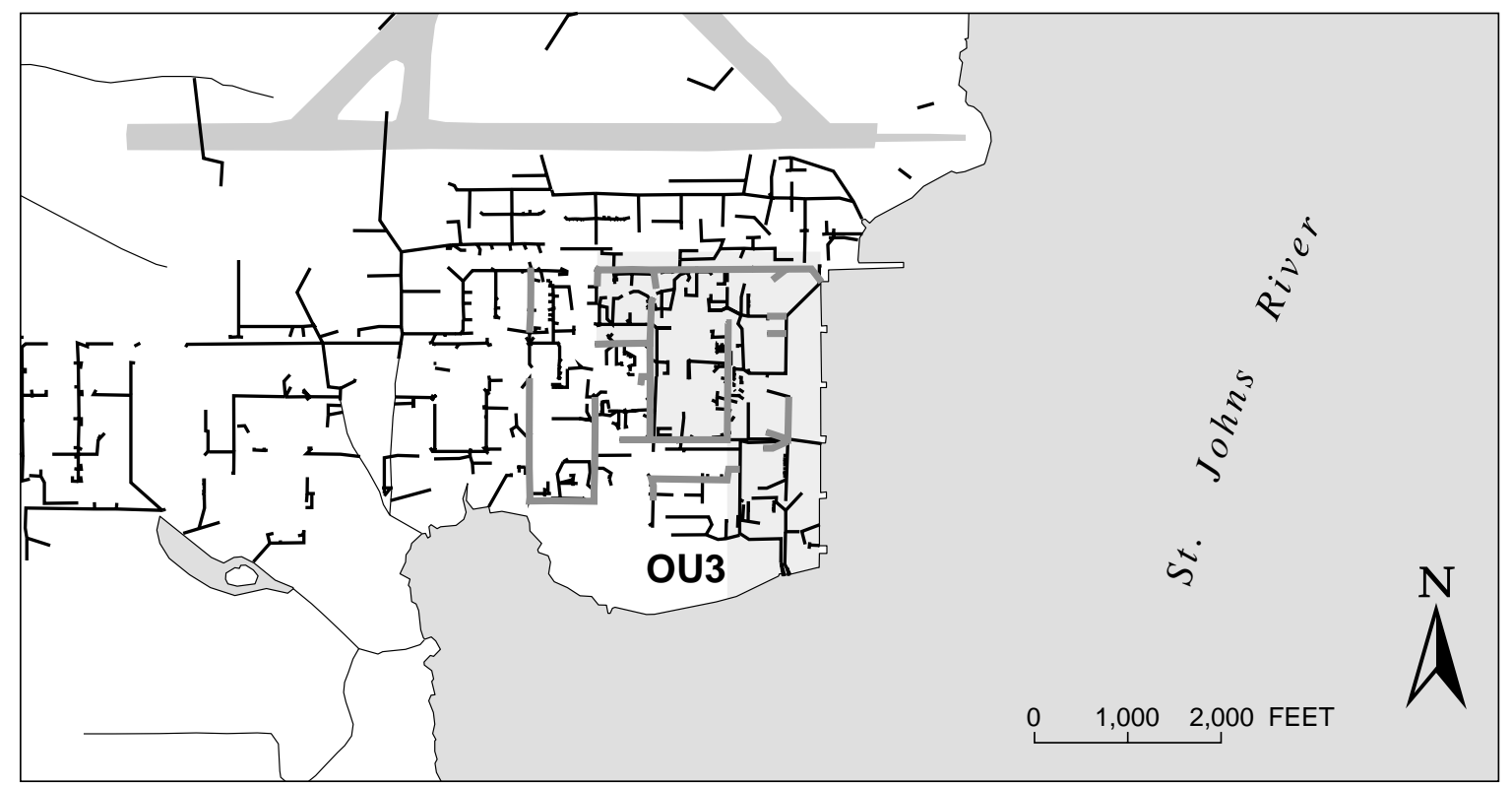

EXPLANATION

ALL IDENTIFIED STORMWATER DRAINS IN AND ADJACENT TO THE SUBREGIONAL STUDY AREA

STORMWATER DRAINS THAT MAY BE DRAINING GROUND WATER FROM THE UPPER LAYER OF THE SURFICIAL AQUIFER

Figure 13. Stormwater drain system at the Jacksonville Naval Air Station.

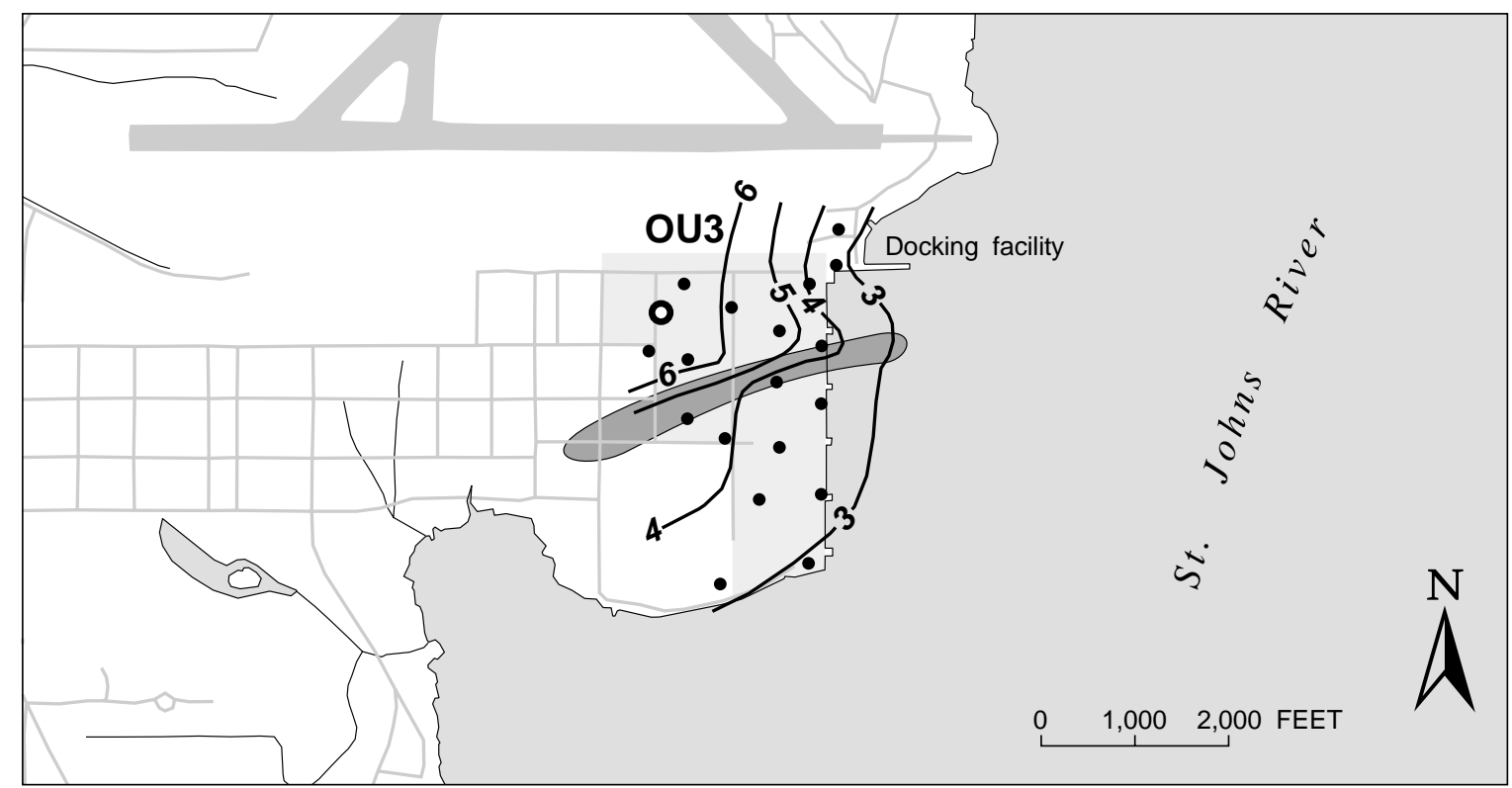

EXPLANATION

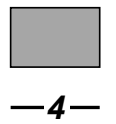

LOW-PERMEABILITY CHANNEL-FILL DEPOSITS

POTENTIOMETRIC CONTOUR-Shows level to which water would have stood in tightly cased wells tapping the intermediate layer of the surficial aquifer. Contour interval 1 foot. Datum is sea level

- $\quad$ MONITORING WELL LOCATION

- AQUIFER TEST LOCATION-Test conducted in the intermediate layer

Figure 14. Potentiometric surface for the intermediate layer of the surficial aquifer on October 29 and 30, 1996, within the subregional study area. 
At the northeastern corner of OU3 is a docking facility (formerly used to off load fuel barges) that projects out into the St. Johns River (fig.14). A channel was dredged in the river bottom to allow barge access to the dock. This dredging probably removed most or all of the upper layer of the surficial aquifer and may have removed or disturbed part of the underlying clay layer. The potentiometric contours near the dock appear relatively depressed, indicating that ground water could be discharging from the intermediate layer in this area.

A multiple-well aquifer test (location shown on fig. 14) was conducted on the intermediate layer, and a horizontal hydraulic conductivity of $20 \mathrm{ft} / \mathrm{d}$ was determined (U.S. Geological Survey data, 1997). During the test, the intermediate layer was pumped at $17 \mathrm{gal} / \mathrm{min}$. Water levels were recorded in three sets of nested piezometers located 20, 50, and $100 \mathrm{ft}$ from the pumping well. Each set of piezometers consisted of 3 wells; one was screened at the base of the upper layer, one near the top of the intermediate layer, and one near the bottom of the intermediate layer. The aquifer test lasted about 21 hours. At 250 minutes into the test, the rate of drawdown in the piezometers screened in the intermediate layer doubled, indicating that the cone of depression had reached the low-permeability channel-fill deposits.

A clay layer separates the upper and intermediate layers in some areas (fig. 15), and has a very low vertical permeability. During the aquifer test discussed above, drawdowns in the wells completed in the intermediate layer were as much as $1.6 \mathrm{ft}$, whereas wells completed in the upper layer ( $5 \mathrm{ft}$ of screen immediately above the clay) showed no response to pumping during the entire test. This indicates that the effect of pumping did not cross the clay layer for the duration of the aquifer test.

The vertical head differences between the intermediate and upper layers ranged from $3.09 \mathrm{ft}$ in the northwestern part of OU3 to $-1.53 \mathrm{ft}$ in the northeastern part (fig. 16). In this figure, positive head differences indicate an upward gradient and negative head differences indicate a downward gradient. The pattern of head differences is caused by a combination of factors (fig. 17). Heads in the upper layer generally increase uniformly from the coast to inland areas, except in the northern part of OU3 where they are relatively lower due to ground-water discharge to leaking stormwater drains (figs. 12 and 17). Heads in the intermediate layer also increase from the coast to inland areas, but the gradient varies north and south of the channel-fill deposits. The horizontal gradient in the intermediate layer is steeper north of the channel-fill deposits, because lateral flow is partially impeded by the deposits. As a result, there is a relatively large drop in heads in the intermediate layer from north to south across the deposits and there is a corresponding reversal in vertical gradients (figs. 14, 16, and 17). Near the docking facility, heads in the intermediate layer are relatively low due to the effects of dredgings, and heads in the upper layer are relatively high due to the damming effect of the seawall. This results in a downward vertical gradient in this area. Within the subregional study area, the vertical head differences were known only at OU3 because this is the only area where nested wells were installed.

The surficial aquifer is bounded below by the low-permeability clays of the Hawthorn Group (fig. 18). The sands, silts, and clays of the surficial aquifer grade into silts and clays of the Hawthorn Group. At OU3, the exact contact between the surficial aquifer and the Hawthorn Group was difficult to recognize. In selecting the top of the Hawthorn Group, the deeper well picks were used because they were more representative of the actual top. The Hawthorn Group is about $300 \mathrm{ft}$ thick at the Station.

\section{GROUND-WATER FLOW SIMULATION AT OPERABLE UNIT 3}

A subregional model was developed to investigate ground-water flow at OU3. The surficial aquifer in the area of OU3 consists of two distinct layers with differing hydrologic characteristics, as discussed previously. For this reason, a subregional multiple-layer model was needed to accurately simulate and delineate ground-water flow beneath OU3. Computer modeling of ground-water flow was performed using MODFLOW (McDonald and Harbaugh, 1988), ground-water flow rates were determined using ZONEBUDGET (Harbaugh, 1990), sensitivity analysis was performed using the calibrated model, and MODPATH (Pollock, 1989) was used to determine the direction and velocity of ground-water flow. 


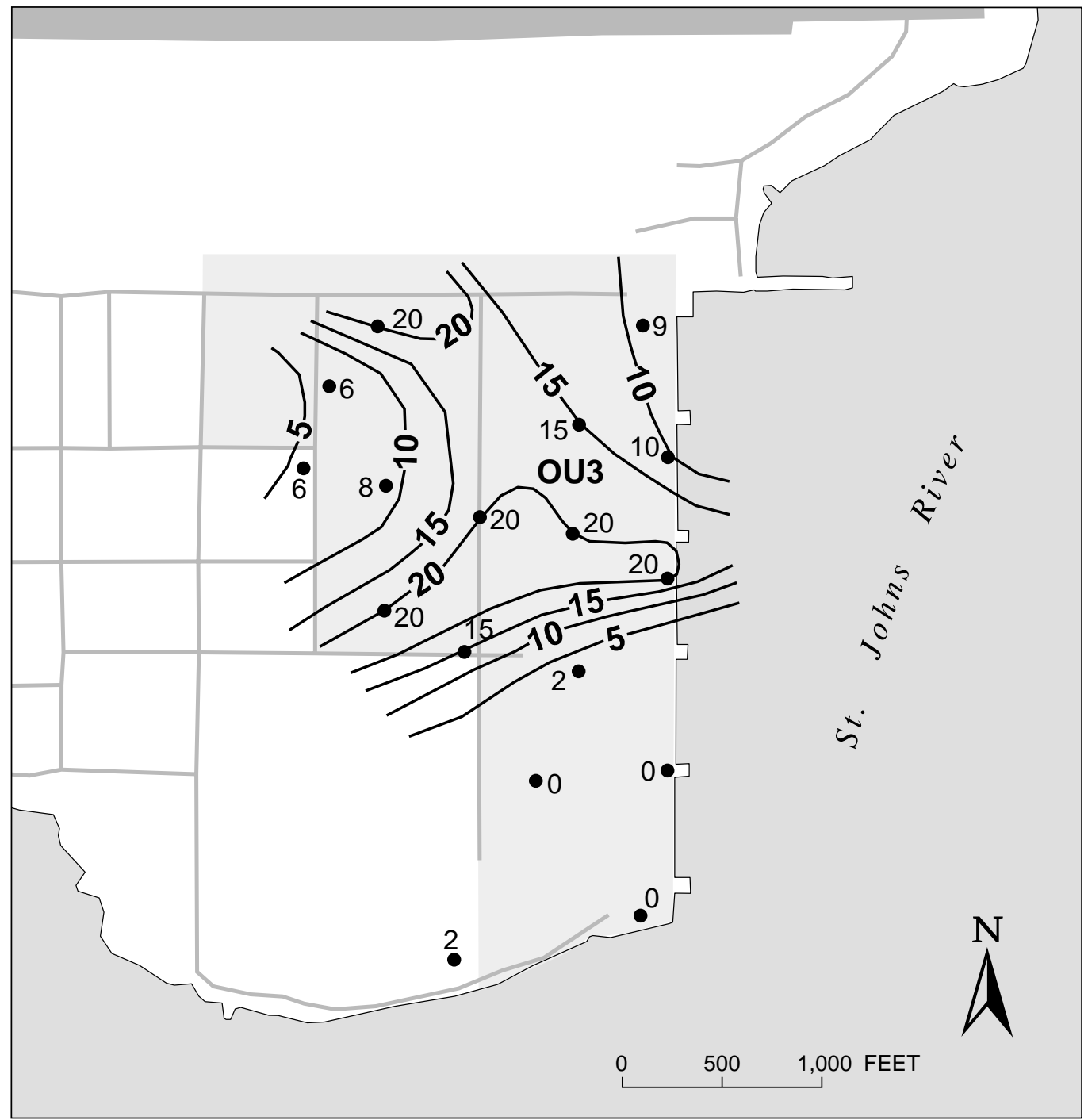

\section{EXPLANATION}

-5- THICKNESS OF CLAY THAT SEPARATES THE UPPER AND INTERMEDIATE
LAYERS-Contour interval 5 feet

-2 WELL-Number is thickness of clay, in feet

Figure 15. Thickness of the clay layer that separates the upper and intermediate layers of the surficial aquifer. 


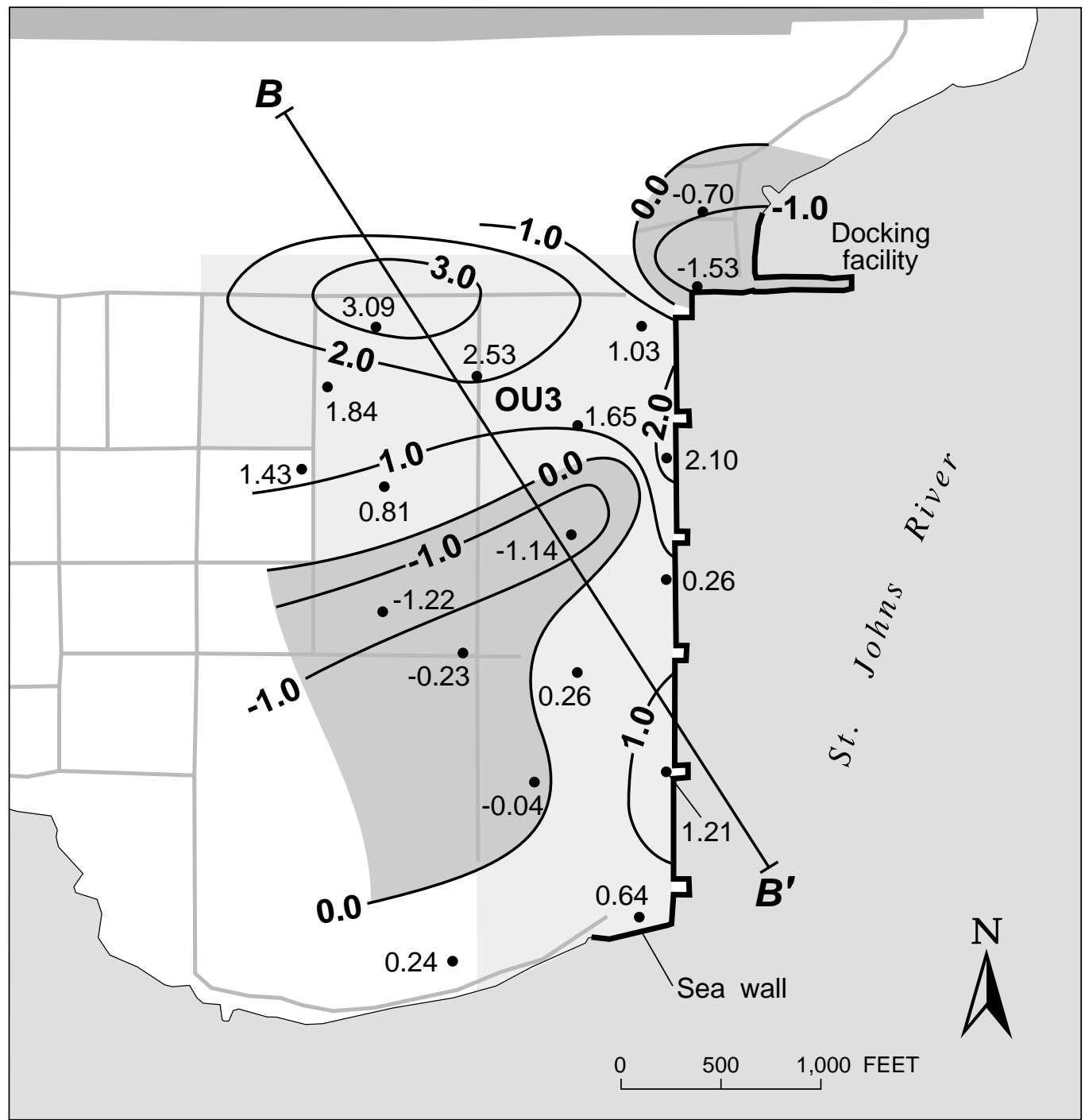

EXPLANATION

AREA IN WHICH THE VERTICAL GROUND-WATER GRADIENT IS DOWNWARD

$\stackrel{\boldsymbol{B}^{\prime}}{\boldsymbol{B}} \quad$ LINE OF SECTION SHOWN IN FIGURE 17

-1.0- HEAD DIFFERENCE CONTOUR-Shows line of equal difference in measured head between the intermediate and upper layers of the surficial aquifer. Contour interval
1 foot

- 0.24 WELL-Number is difference in measured head between the intermediate and upper layers of the surficial aquifer. Positive values indicate upward gradient, negative values indicate downward gradient. Values in feet

Figure 16. Head difference between the intermediate and upper layers of the surficial aquifer. 


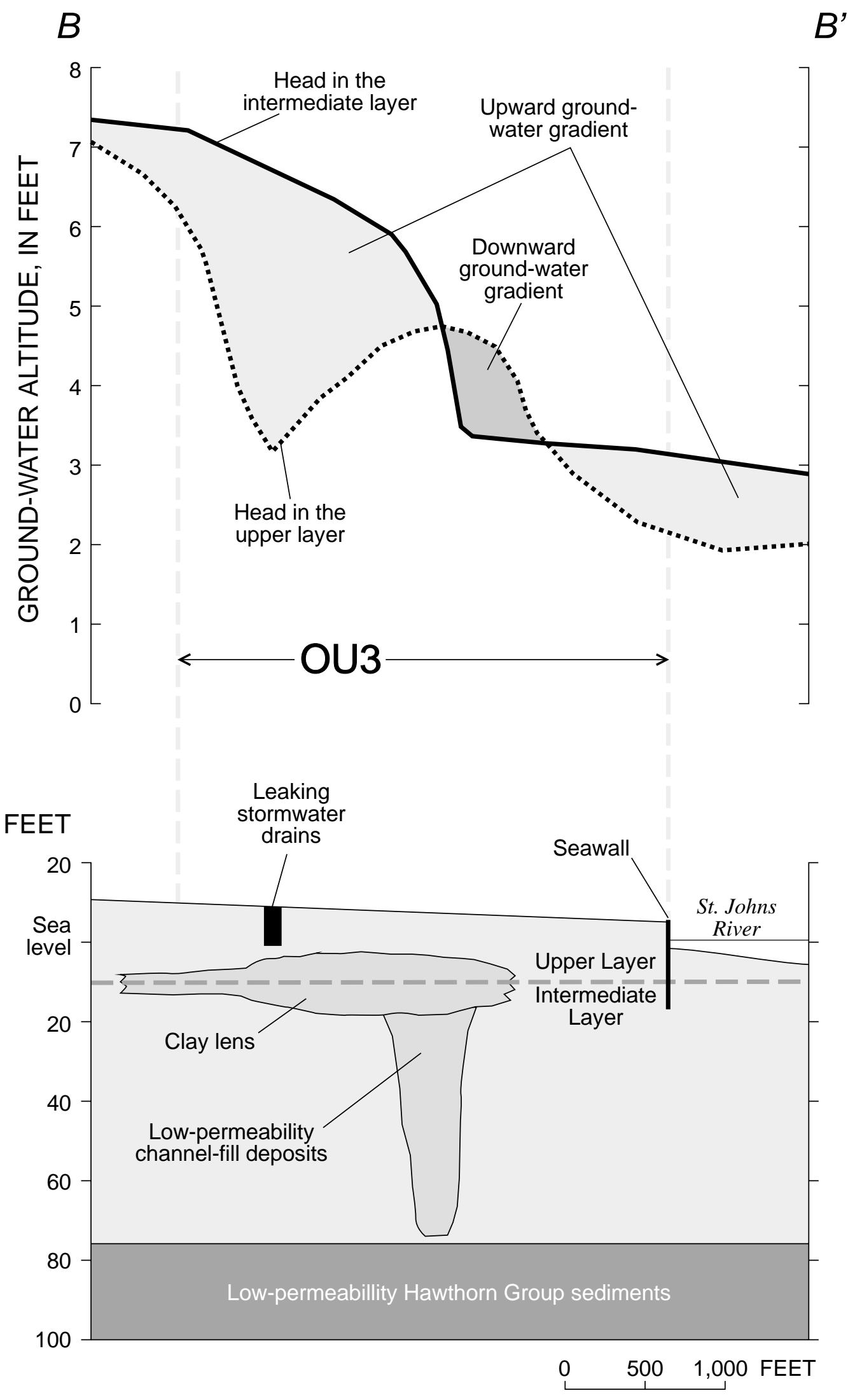

Figure 17. Generalized hydrologic section for the subregional model. 


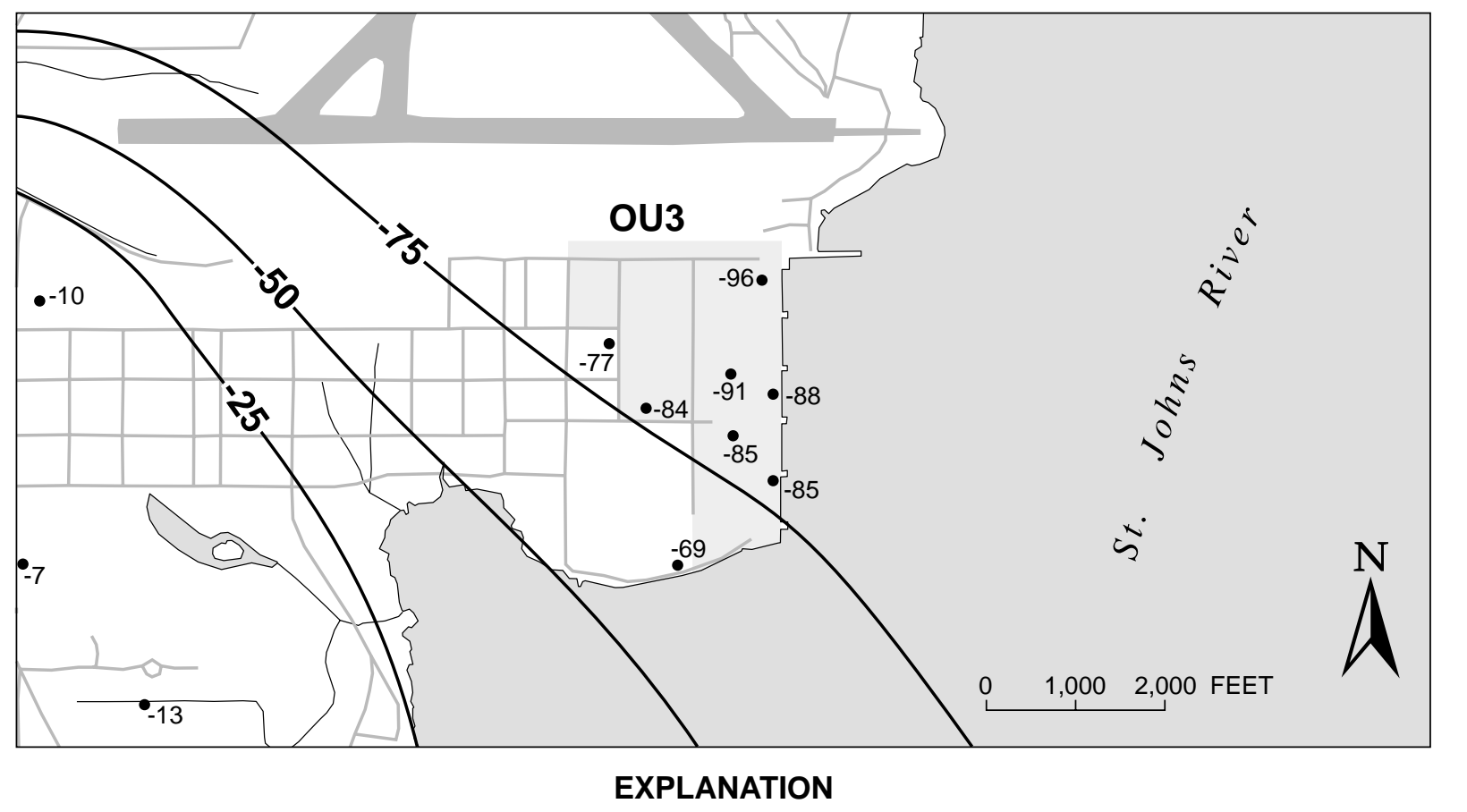

-10- STRUCTURE CONTOUR-Shows altitude of the top of the Hawthorn Group. Contour interval
25 feet. Datum is sea level

- -13 WELL-Number is the altitude of the top of the Hawthorn Group, in feet

Figure 18. Top of the Hawthorn Group.

\section{Model Construction}

The location and orientation of the finite-difference grid is shown in figure 19. There are 78 rows and 148 columns of active model cells; all cells are $100 \mathrm{ft}$ on each side. Vertically, the surficial aquifer was divided into two layers (fig. 20). The upper model layer represents the upper layer of the surficial aquifer and extends from land surface down to $15 \mathrm{ft}$ below sea level; this layer was modeled as unconfined. The lower model layer represents the intermediate layer and extends from the bottom of the upper layer (or the bottom of the clay layer where present) down to the top of the Hawthorn Group; this layer was modeled as confined. The clay layer was not modeled explicitly, but the effect of the clay layer was simulated through the vertical leakance between the upper and intermediate layers. The seawall was simulated using the Horizontal-Flow Barrier Package documented by Hsieh and Freckleton (1993).

The northern, western, and southern boundaries of the model are no flow and were positioned along ground-water divides or flow lines delineated with the regional model (fig. 7). The eastern model boundary is also no flow and is positioned near the center of the St. Johns River. This boundary was positioned away from the shoreline so that the model could simulate the upward seepage of ground water through the bottom of the river. The base of the surficial aquifer was simulated as a no-flow boundary because it is underlain by the lowpermeability sediments of the Hawthorn Group. There is little, if any, vertical flow between the surficial aquifer and the Hawthorn Group. 


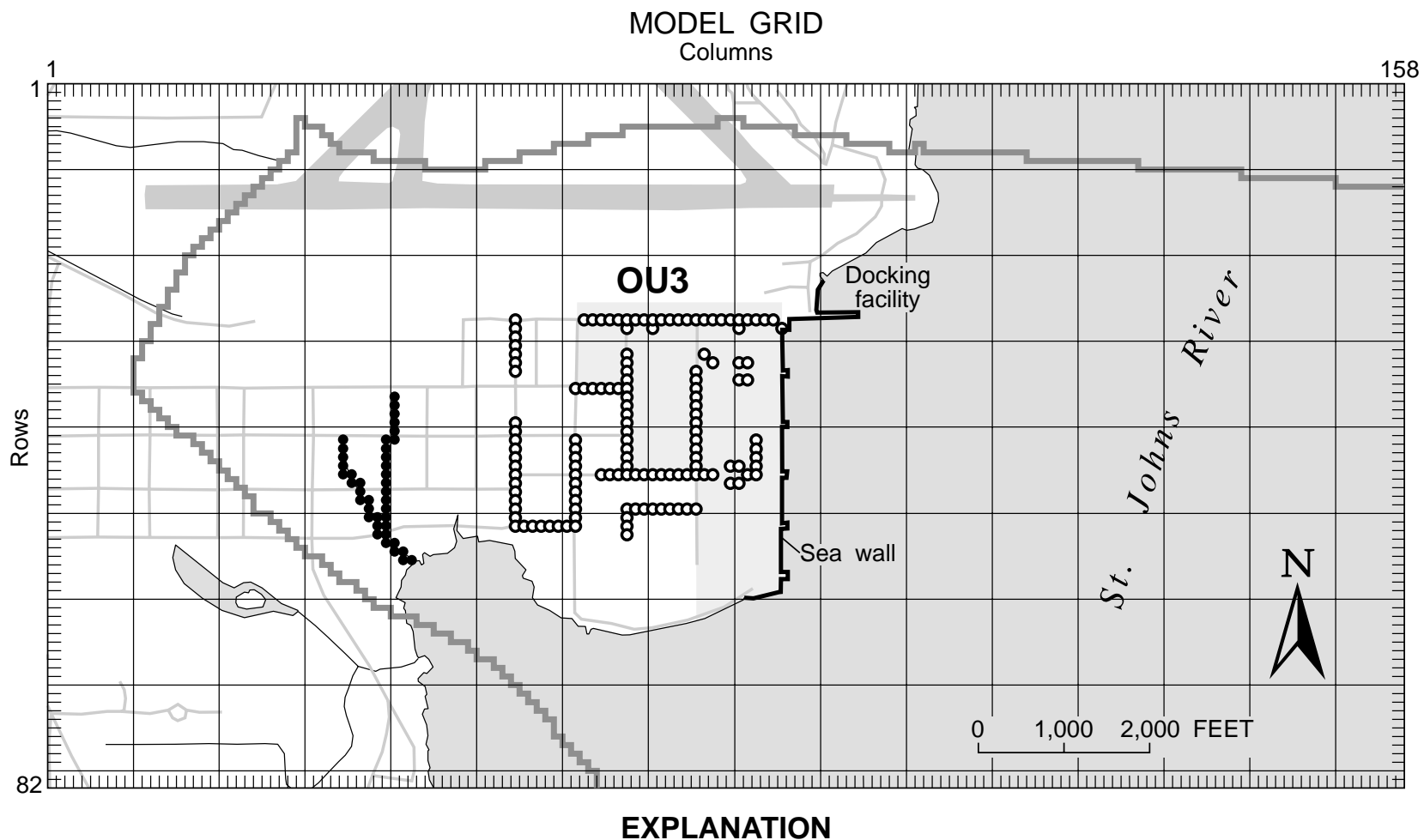

BOUNDARY OF ACTIVE CELLS FOR $\quad \infty 00$ DRAIN CELLS $\quad \infty 00$ RIVER CELLS
BOTH MODEL LAYERS

NOTE: The St. Johns River was modeled using river cells

Figure 19. Location and orientation of the subregional model finite-difference grid.

The MODFLOW River Package was used to simulate the presence of the St. Johns River and the two small ditches (fig. 19); both the St. Johns River and small ditches were simulated in the upper layer of the model. The riverbed conductance for the St. Johns River was calculated using a riverbed thickness of $1 \mathrm{ft}$ over the entire area of each cell. The initial riverbed conductance was $10 \mathrm{ft}^{2} / \mathrm{d}$, which was the calibrated value from the regional model. The altitude of the bottom of the river was taken from USGS topographic maps and a stage of $1 \mathrm{ft}$ above sea level was assumed. Conductance for the two small ditches was calculated using a thickness of $1 \mathrm{ft}$ and a width of $10 \mathrm{ft}$. The initial conductance was $4 \mathrm{ft}^{2} / \mathrm{d}$, which was the calibrated value from the regional model. The altitude of the stage and bottom of the two ditches was estimated from the topographic maps and field observations.

The MODFLOW Drain Package was used to simulate the presence of the stormwater drains in the upper layer. The altitude relative to sea level of the bottom of the drains was determined where manholes allowed access. The altitudes between manholes was extrapolated from the measured values. The conductance of the drains was varied during model calibration.

The initial rate and distribution of recharge was taken from the calibrated regional model and ranged from $13.0 \mathrm{in} / \mathrm{yr}$ in irrigated areas to $0.05 \mathrm{in} / \mathrm{yr}$ in paved areas. The initial horizontal hydraulic conductivity for the upper layer was set at $0.5 \mathrm{ft} / \mathrm{d}$ for all of OU3 (and the entire eastern half of the subregional model area) based on the results of the aquifer and slug tests discussed previously. The transmissivity of the intermediate layer outside the low-permeability channel-fill deposits was calculated using a horizontal hydraulic conductivity of $20 \mathrm{ft} / \mathrm{d}$ (the value determined by aquifer testing); within the channel-fill deposits the horizontal hydraulic was assumed to be $0.2 \mathrm{ft} / \mathrm{d}$ or two orders of magnitude lower. 

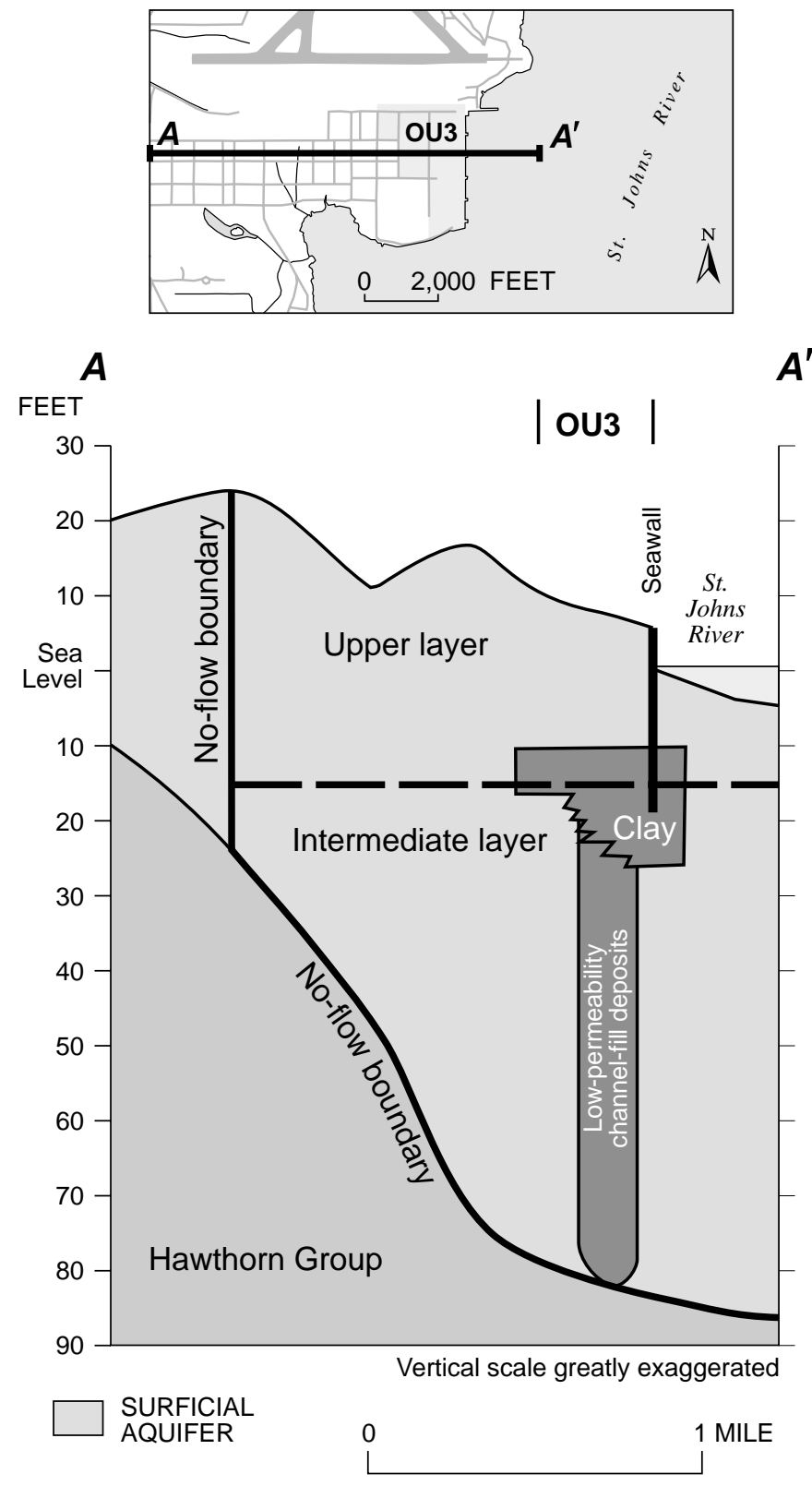

Figure 20. Generalized hydrologic section for the subregional model.

\section{Model Calibration}

The model was calibrated to the head data collected on October 29 and 30, 1996. Steady-state ground-water flow conditions were assumed for reasons discussed earlier. The calibration strategy was to match simulated heads in both the upper and intermediate layers to within $1 \mathrm{ft}$ of the measured values. The location of wells with measured heads used for calibration of the upper layer are shown in figure 10 (only wells within the subregional model boundary were used) and for the intermediate layer are shown in figure 11. Ideally, there would also be a match of simulated flows in the river cells to field measurements; however, due to the difficulty of measurement, no flow rate was determined in the small ditches within the subregional model area and the rate of discharge of ground water to the St. Johns River is unknown. All of the available streamflow measurements fell outside the subregional model area boundary. For these reasons, there were no discharge measurements to compare with simulated values during calibration. Fortunately, the hydraulic conductivities in both the upper and intermediate layers were determined by aquifer testing, thus constraining the model solution.

Calibration of the model was achieved by varying recharge, hydraulic conductivity in the upper layer (within a narrow range of the values determined by aquifer and slug tests), transmissivity of the low-permeability channel-fill deposits in the intermediate layer, vertical leakance, riverbed conductance, and drain conductance. During the

calibration process, changes in the recharge rates in the subregional model were also applied to the regional model. If the positions of the ground-water divides or flow lines in the regional model shifted, then the boundaries of the subregional model were moved correspondingly; this was an iterative process and done to ensure that the boundaries of the subregional model remained as "no-flow."

After calibration, all of the model simulated heads matched the measured heads within the calibration criterion of $1 \mathrm{ft}$, and 48 of 67 simulated heads ( 72 percent) were within $0.5 \mathrm{ft}$ of the corresponding measured values. Figure 21 shows a comparison of the measured and simulated heads. If the model simulated heads had matched the measured values exactly, then all the points would lie on the 45 degree line (line of equality). 
The only change to the simulated recharge rate during calibration was an increase from 0.05 to $0.4 \mathrm{in} / \mathrm{yr}$ in the paved area at and around OU3 (fig. 22). The increase was needed to raise the simulated heads at OU3. The relatively low recharge rate of $0.4 \mathrm{in} / \mathrm{yr}$ is believed to be reasonable, because this area is largely paved and runoff is carried away by the stormwater drainage system. The horizontal hydraulic conductivities at OU3 were determined by aquifer tests and the simulated horizontal hydraulic conductivities were set at or near these values; because of this, the recharge rate at OU3 could only be varied within a narrow range during calibration.

The model simulated horizontal hydraulic conductivity distribution for the upper layer is shown in figure 23. In the northern central part of the subregional model area the hydraulic conductivity is $0.5 \mathrm{ft} / \mathrm{d}$, which is very nearly the value of $0.6 \mathrm{ft} / \mathrm{d}$ determined by the multiple-well aquifer test. The hydraulic conductivity in the southern part of OU3 was increased slightly to $1.0 \mathrm{ft} / \mathrm{d}$ to lower the simulated heads in this area. In the western part of the subregional model area, the hydraulic conductivity was $7.5 \mathrm{ft} / \mathrm{d}$ which was the calibrated value for the regional model and near the measured value of $5.0 \mathrm{ft} / \mathrm{d}$ determined at OU1.

The model-simulated vertical leakance between the upper and intermediate layers is shown in figure 24 . Over most of the modeled area, the vertical leakance ranged from $4.0 \times 10^{-4}$ to $4.0 \times 10^{-5} \mathrm{~d}^{-1}$, which is roughly equivalent to a vertical hydraulic conductivity that is two to three orders of magnitude lower than the horizontal hydraulic conductivity. Where the clay layer is present, the vertical leakance is $1.0 \times 10^{-6} \mathrm{~d}^{-1}$, which is roughly equivalent to a vertical hydraulic conductivity that is five orders of magnitude lower than the horizontal conductivity. In the area that was dredged, the vertical leakance was adjusted to $4.3 \times 10^{-2} \mathrm{~d}^{-1}$ which reflects the possible disturbance of the clay layer in this area.

The model-simulated transmissivity in the intermediate layer is shown in figure 25 . The transmissivity increases from less than $200 \mathrm{ft}^{2} / \mathrm{d}$ on the western boundary to about $1,200 \mathrm{ft}^{2} / \mathrm{d}$ at OU3. The increase from west to east is a result of the thickening of the intermediate layer due to the deepening of the top of the Hawthorn Group. The transmissivity (except in the low-permeability channel-fill deposits) was calculated using a
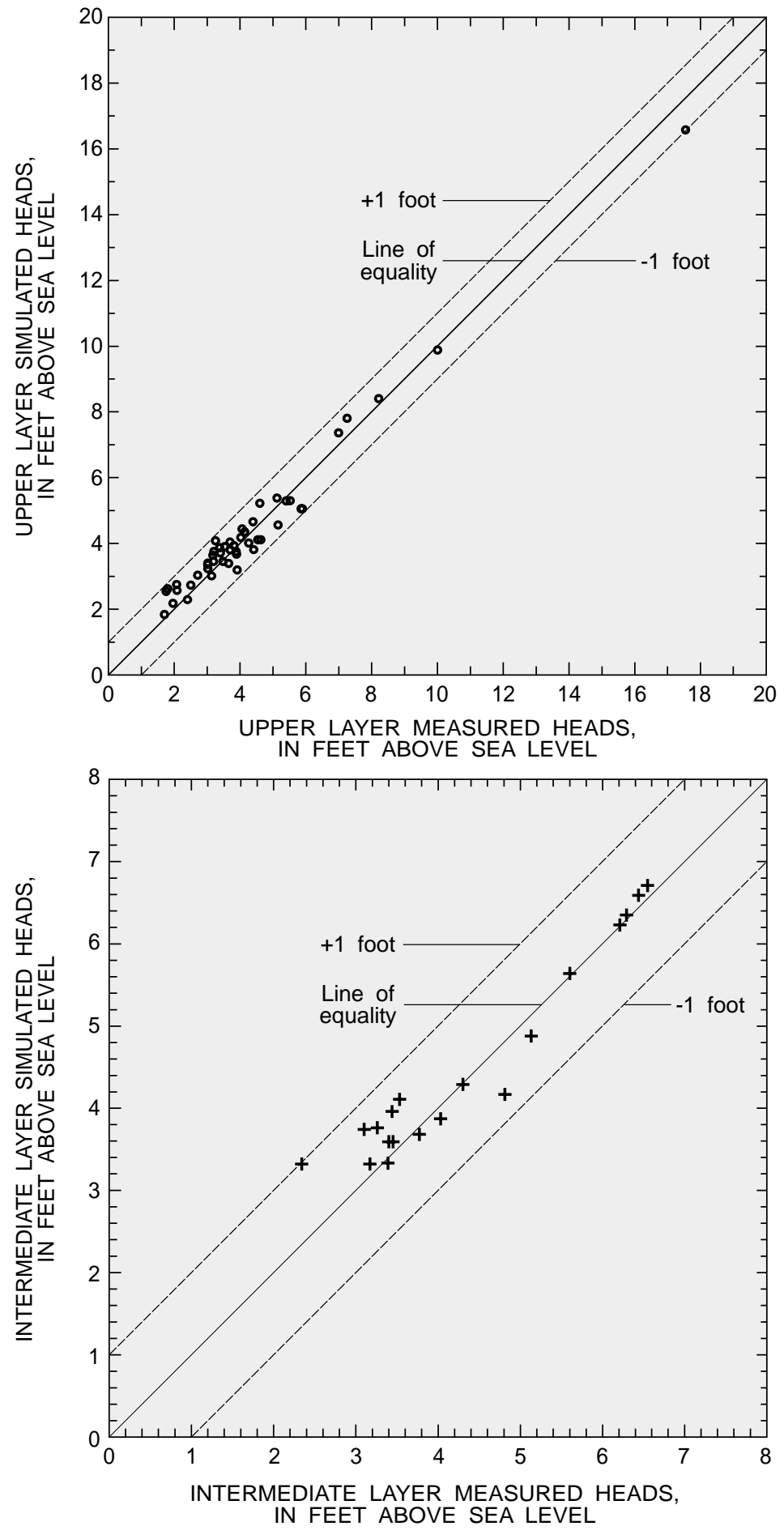

Figure 21. Comparison of measured and simulated heads for the subregional model. 


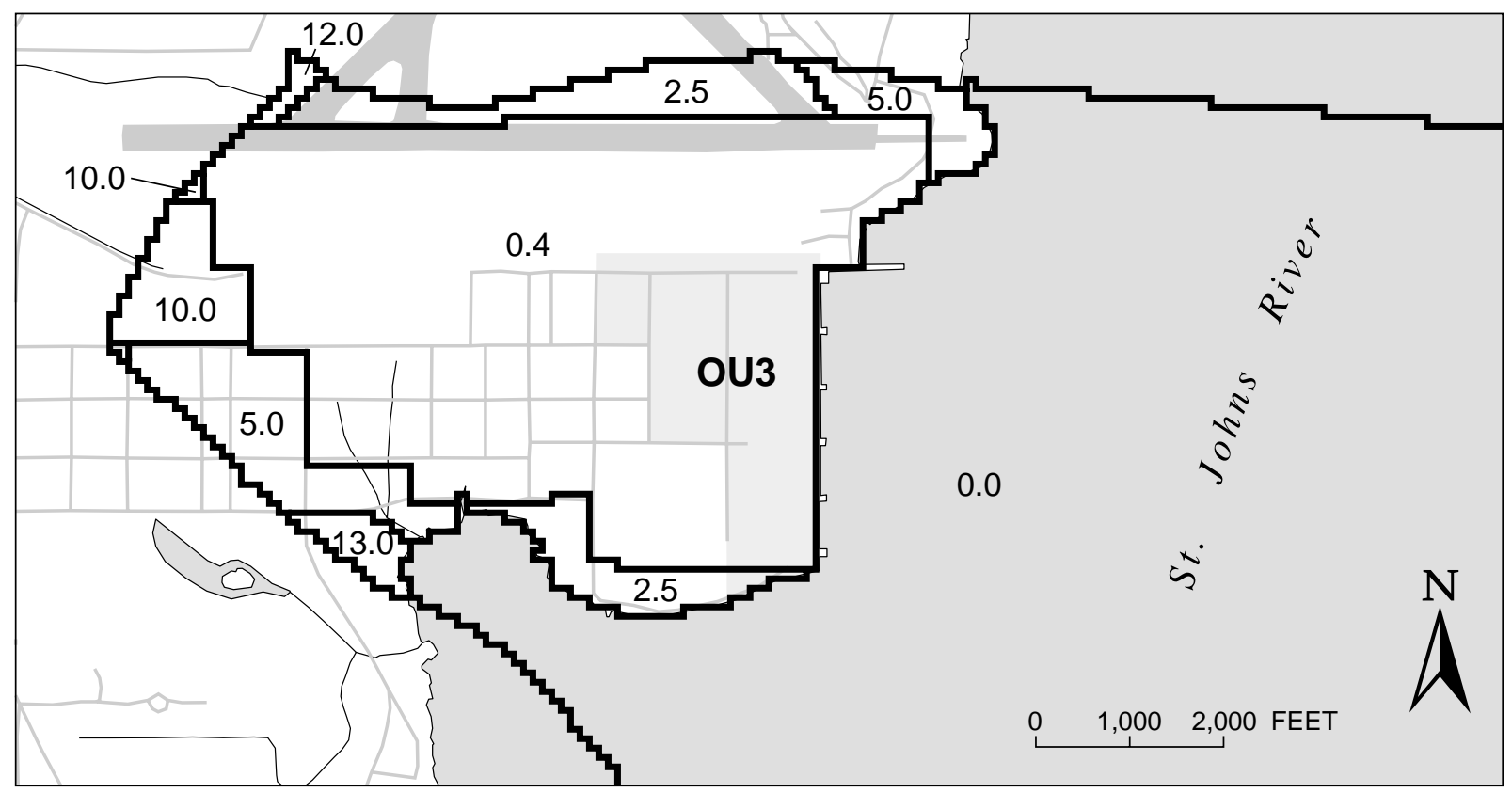

\section{EXPLANATION}

BOUNDARY OF RECHARGE ZONES IN MODEL

2.5 RECHARGE RATES-Model simulated, values in inches per year

Figure 22. Simulated recharge rates for the subregional model.

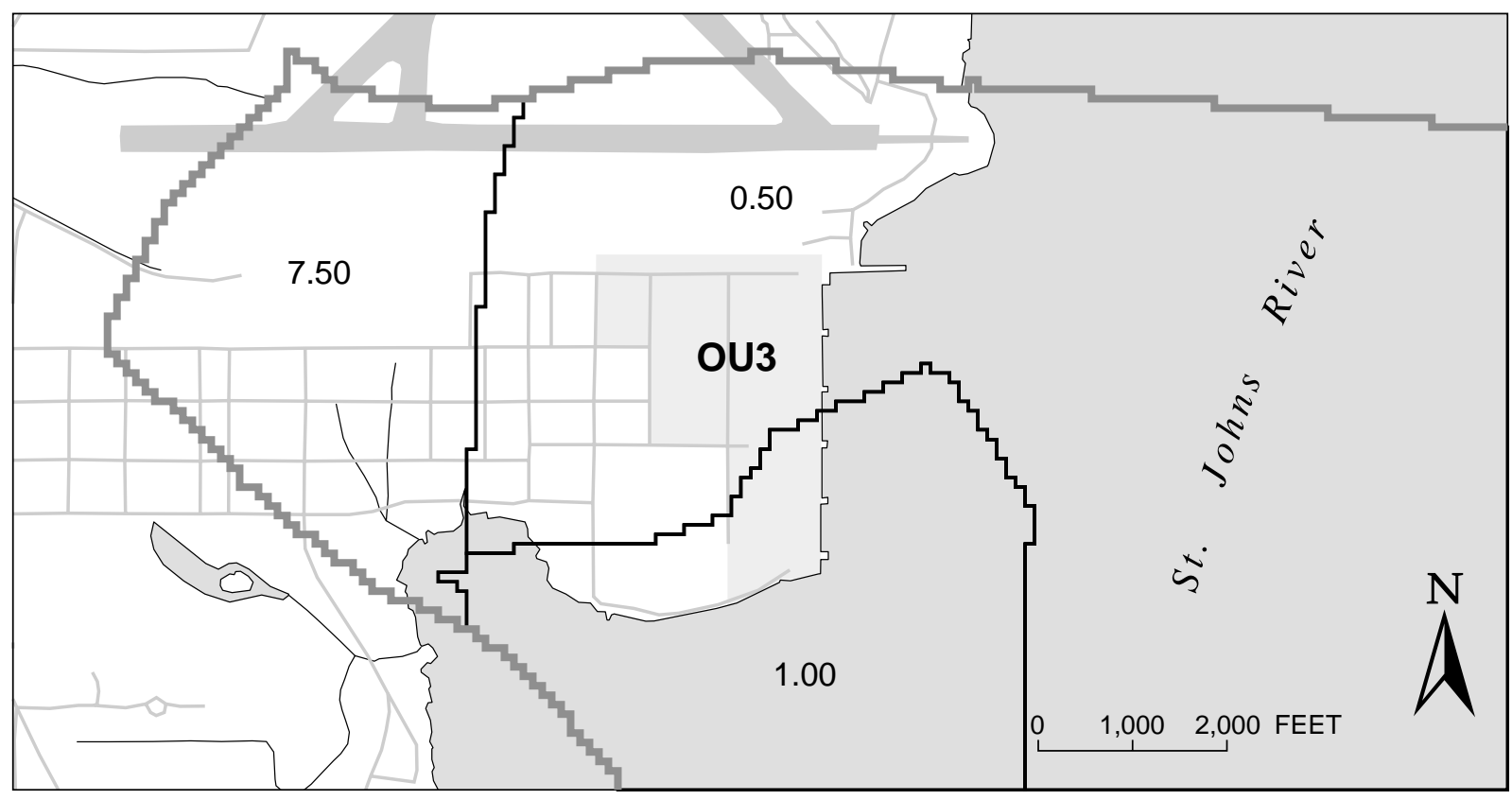

EXPLANATION

- SUBREGIONAL STUDY AREA AND SUBREGIONAL MODEL BOUNDARY

7.50 MODEL-SIMULATED HORIZONTAL HYDRAULIC CONDUCTIVITY IN THE UPPER LAYER-In feet per day

Figure 23. Simulated horizontal hydraulic conductivity of the upper layer of the subregional model. 
constant hydraulic conductivity of $20 \mathrm{ft} / \mathrm{d}$, which was the value determined by aquifer testing. The transmissivity of the low-permeability channel-fill deposits was determined during model calibration to be $25 \mathrm{ft}^{2} / \mathrm{d}$, yielding a hydraulic conductivity of $0.4 \mathrm{ft} / \mathrm{d}$. The low transmissivity was required to match the steep potentiometric gradient within the channel-fill deposits.

The riverbed conductance for the St. Johns River was decreased from the regional model value of 10 to $8 \mathrm{ft}^{2} / \mathrm{d}$ during calibration, except in the area of the docking facility where the conductance was increased to $60 \mathrm{ft}^{2} / \mathrm{d}^{2}$ reflect the disturbance and removal of riverbed sediments during dredging. The conductance of the small ditches was not changed from the initial value of $4 \mathrm{ft}^{2} / \mathrm{d}$. The calibrated conductances of the stormwater drains ranged from 5 to $20 \mathrm{ft}^{2} / \mathrm{d}$.

The simulated water table for the upper layer is shown in figure 26. The water table slopes toward the St. Johns River except in areas that are influenced by the leaking stormwater drains. Almost all of the simulated drains caused some depression in the water-table surface because they are removing ground water from the upper layer of the aquifer. The presence of the seawall cause elevated heads to occur directly adjacent to the St. Johns River in the central and northern parts of OU3. The heads are relatively higher in this area because the seawall extends downward into the clay and prevents ground water from moving easily under the seawall and discharging to the St. Johns River. Along the southern end of the seawall, the heads are lower because the clay is much thinner and less continuous, thus allowing ground water to move under the wall. There is some evidence that seepage also occurs through joints in the seawall.
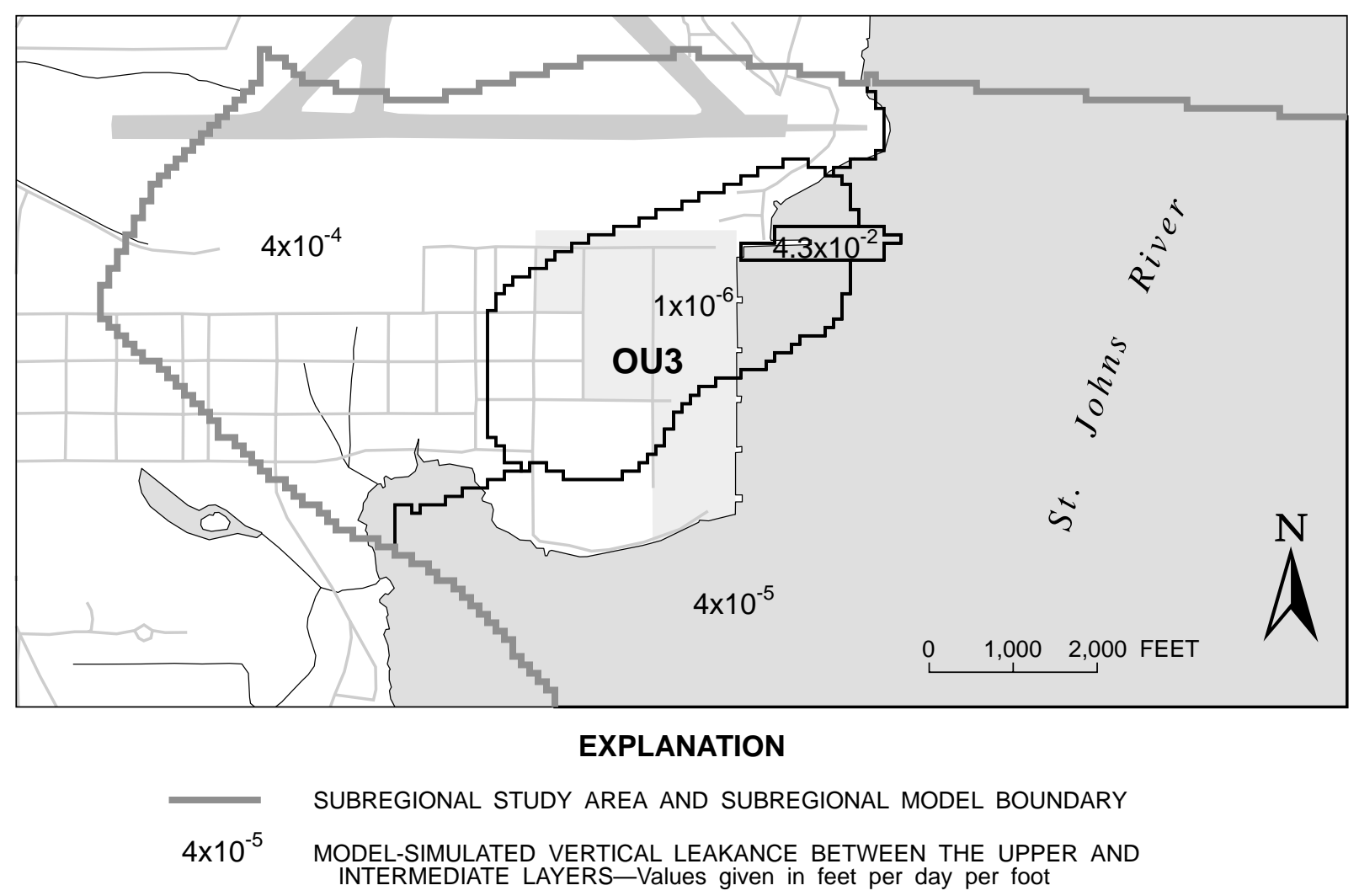

Figure 24. Simulated vertical leakance between the upper and the intermediate layers of the subregional model. 


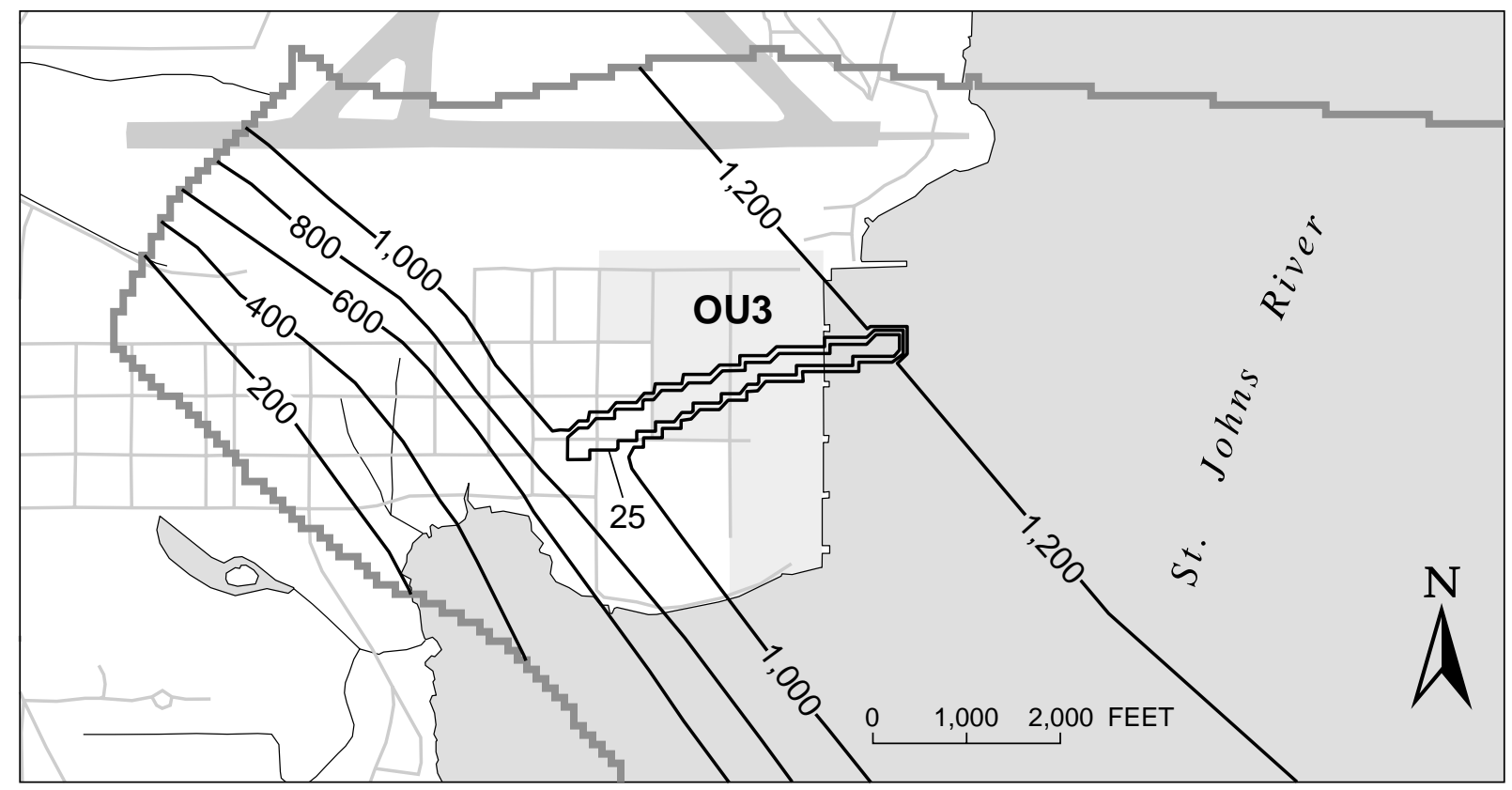

EXPLANATION

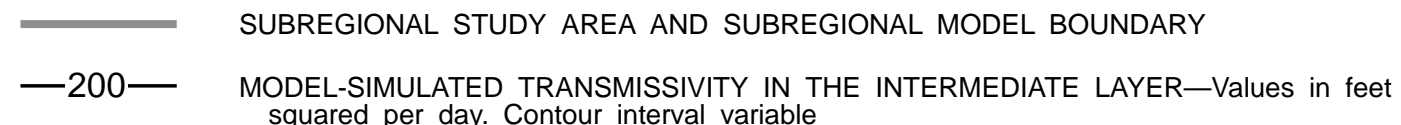

Figure 25. Simulated transmissivity for the intermediate layer of the subregional model.

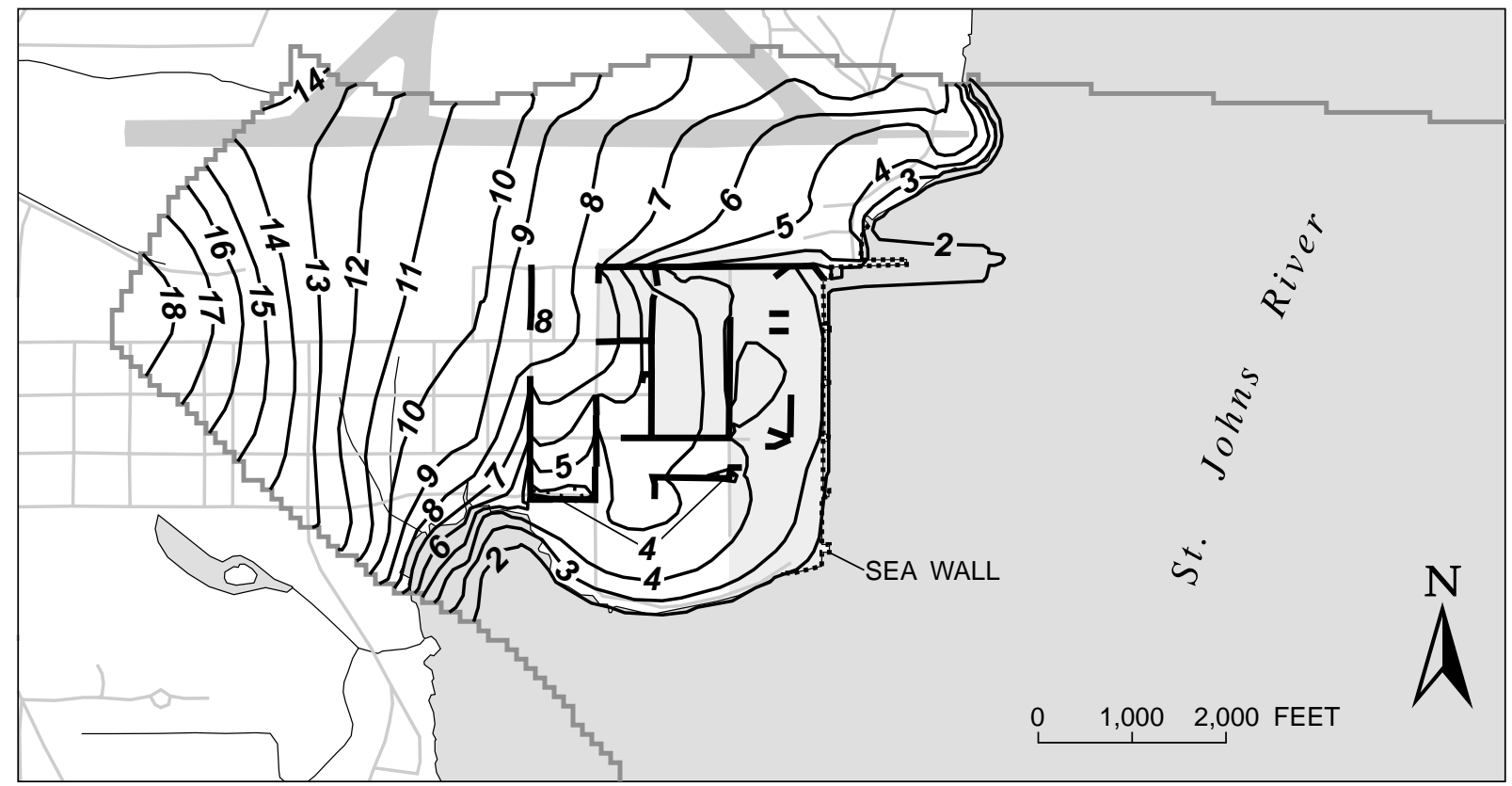

\section{EXPLANATION}

-4- SIMULATED WATER TABLE CONTOUR-Shows model simulated head in the upper layer. Contour interval 1 foot. Datum is sea level

\section{SIMULATED LEAKING STORMWATER DRAINS}

Figure 26. Simulated water table surface of the upper layer of the subregional model. 


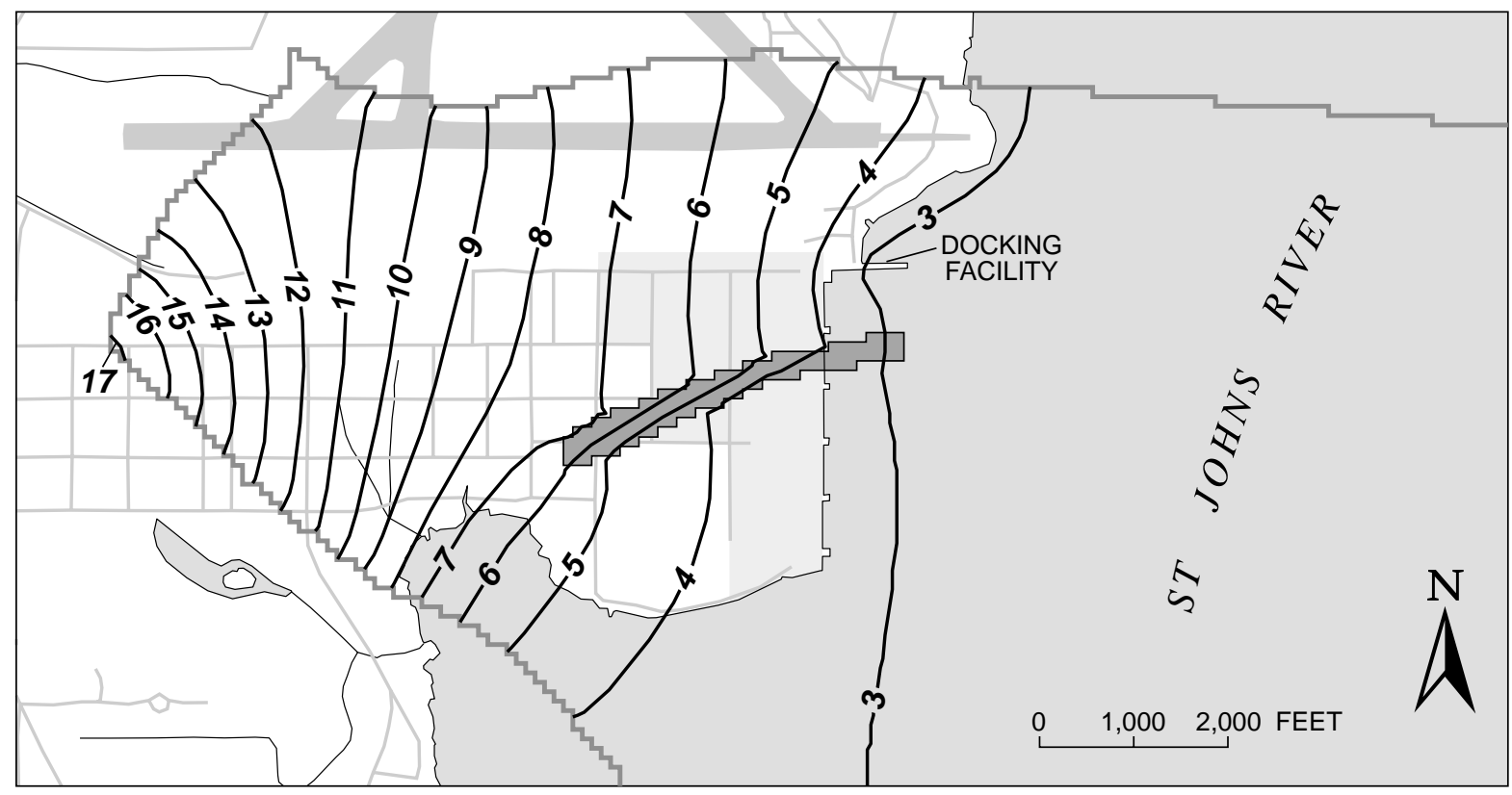

\section{EXPLANATION}

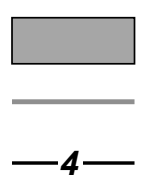

LOW-PERMEABILITY CHANNEL-FILL DEPOSITS

SUBREGIONAL STUDY AREA AND SUBREGIONAL MODEL BOUNDARY

SIMULATED POTENTIOMETRIC CONTOUR-Shows model simulated head in the intermediate layer. Contour interval 1 foot. Datum is sea level

Figure 27. Simulated potentiometric surface of the intermediate layer of the subregional model.

The simulated potentiometric surface for the intermediate layer slopes toward the St. Johns River (fig. 27). The presence of the low-permeability channel-fill deposits is reflected in the bending of the contours in the central part of OU3; the result is a steeper slope of the surface in the northern half of OU3 than in the southern half. The increased vertical leakance between the upper and intermediate layers in the vicinity of the docking facility allows ground water to flow more easily upward from the intermediate layer; this is indicated by a slight convergence of the simulated 3- and 4-ft contours at the facility. The measured and model-simulated head differences between intermediate and upper layers are shown in figure 28.

\section{Ground-Water Budget}

The USGS program ZONEBUDGET (Harbaugh, 1990) was used to calculate the model-simulated inflows and outflows for the subregional model area (table 3 ). The total rate of recharge to the subregional model was $0.171 \mathrm{ft}^{3} / \mathrm{s}$; this was the only source of water to the subregional model. Most of the discharge was to the St. Johns River at a rate of $0.145 \mathrm{ft}^{3} / \mathrm{s}$. The total discharge to the lined ditches was $0.012 \mathrm{ft}^{3} / \mathrm{s}$ and the total discharge to the stormwater drains was $0.014 \mathrm{ft}^{3} / \mathrm{s}$. There are $1,250 \mathrm{ft}$ of stormwater drains simulated in the model, giving an average simulated leakage rate of $0.0011 \mathrm{ft}^{3} / \mathrm{s}$ per $100 \mathrm{ft}$ of drain. 


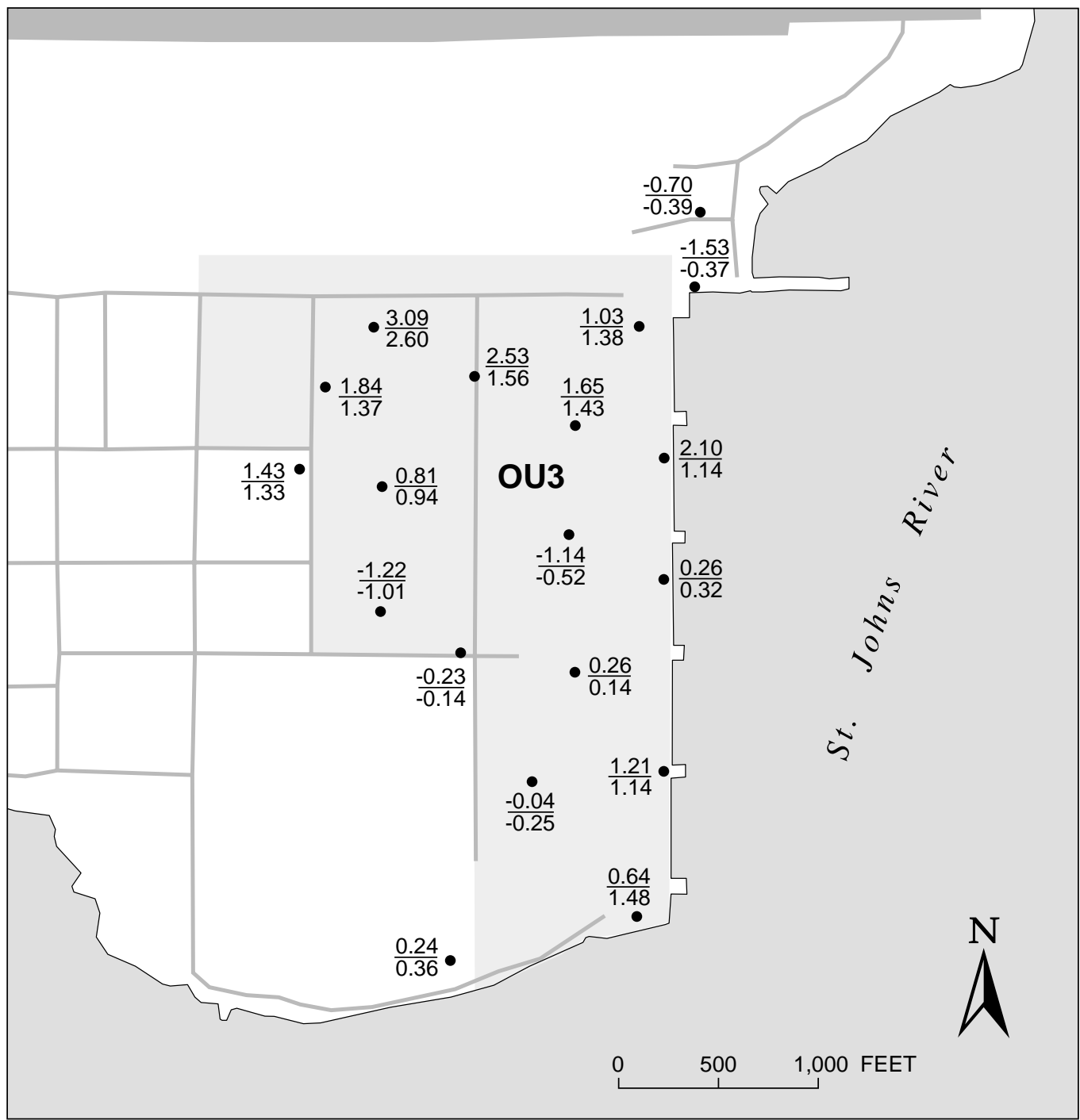

EXPLANATION

- $\frac{0.24}{0.36}$ MEASURED AND MODEL-SIMULATED HEAD DIFFERENCES-Upper value is the measured head difference, in feet, between the intermediate and upper layers of the surficial aquifer. Lower value is the simulated difference. Positive values indicate an upward gradient, negative values indicate a downward gradient

Figure 28. Measured and model-simulated head differences between the intermediate and upper layers of the subregional model. 
Table 3. Simulated ground-water inflows and outflows for the subregional model.

$\left[\mathrm{ft}^{3} / \mathrm{s}\right.$, cubic feet per second]

\begin{tabular}{lcc}
\hline $\begin{array}{c}\text { Ground-water } \\
\text { source or sink }\end{array}$ & $\begin{array}{c}\text { Flow rate into } \\
\text { the model } \\
\left(\mathbf{f t}^{\mathbf{3}} / \mathbf{s}\right)\end{array}$ & $\begin{array}{c}\text { Flow rate out } \\
\text { of the model } \\
\left(\mathbf{f t}^{\mathbf{3}} / \mathbf{s}\right)\end{array}$ \\
\hline Recharge & 0.171 & 0 \\
St. Johns River & 0 & 0.145 \\
Lined ditches & 0 & 0.012 \\
Stormwater drains & 0 & 0.014 \\
Total & 0.171 & 0.171 \\
\hline
\end{tabular}

\section{Sensitivity Analysis}

Sensitivity tests were conducted to determine the effect of changes in model input parameters on the model calibration. Tests were conducted by increasing (or decreasing) each parameter by 50 percent; other parameters were unchanged. Parameter changes resulted in the model simulating a new distribution of heads, and the effect was judged by determining the number of simulated heads that no longer remained within $1.0 \mathrm{ft}$ of the measured values (table 4). Input parameters tested were horizontal hydraulic conductivity of the upper layer, transmissivity of the intermediate layer, vertical leakance, recharge, riverbed conductance, and drain conductance. All of the measured heads used for model calibration were also used for sensitivity analyses.

Table 4. Summary of sensitivity analyses for the subregional model

[*indicates parameter is multiplied by the number to the right].

\begin{tabular}{|c|c|c|c|}
\hline Parameter changed & $\begin{array}{c}\text { Number of simulated heads } \\
\text { in the upper layer that } \\
\text { exceeded the } \\
\text { calibration criterion of } \\
1.0 \text { foot }\end{array}$ & $\begin{array}{c}\text { Number of simulated } \\
\text { heads in the } \\
\text { intermediate layer that } \\
\text { exceeded the calibration } \\
\text { criterion of } 1.0 \text { foot }\end{array}$ & Total \\
\hline Calibrated Model & 0 & 0 & 0 \\
\hline Recharge $* 0.5$ & 18 & 12 & 30 \\
\hline Recharge $* 1.5$ & 20 & 17 & 37 \\
\hline Riverbed conductance $* 0.5$ & 10 & 11 & 21 \\
\hline Riverbed conductance $* 1.5$ & 3 & 1 & 4 \\
\hline Drain conductance $* 0.5$ & 8 & 1 & 9 \\
\hline Drain conductance $* 1.5$ & 2 & 0 & 2 \\
\hline Transmissivity of intermediate layer $* 0.5$ & 6 & 5 & 11 \\
\hline Transmissivity of intermediate layer $* 1.5$ & 5 & 1 & 6 \\
\hline Horizontal hydraulic conductivity of upper layer * 0.5 & 7 & 1 & 8 \\
\hline Horizontal hydraulic conductivity of upper layer * 1.5 & 3 & 0 & 3 \\
\hline Vertical leakance $* 0.5$ & 2 & 4 & 6 \\
\hline Vertical leakance $* 1.5$ & 3 & 0 & 3 \\
\hline
\end{tabular}


The model was sensitive to recharge-rate changes, because recharge was the only source of water to the model. Decreasing the recharge rate by 50 percent caused the total number of simulated heads exceeding the error criterion to increase from 0 to 30 (out of 67). Increasing the recharge rate by 50 percent caused the number of heads exceeding the error criterion to increase from 0 to 37.

Decreasing the riverbed conductance caused the simulated heads to rise, because a larger gradient was necessary to move water from the aquifer to the river. A decrease of 50 percent caused the total number of simulated heads exceeding the error criterion to increase from 0 to 21 . In contrast, the model was less sensitive to increases in riverbed conductance. An increase of 50 percent caused the number of simulated heads exceeding the error criterion to increase from 0 to 4 .

Decreasing the drain conductance caused the simulated heads in the vicinity of the drains to rise, because a larger vertical gradient developed between the drains and the aquifer. A decrease of 50 percent caused the number of simulated heads exceeding the error criterion to increase from 0 to 8 in the upper layer. The model was less sensitive to an increase in drain conductance. An increase of 50 percent caused the number of simulated heads exceeding the error criterion in the upper layer to increase from 0 to 2 . As expected, varying the drain conductance had little effect on the heads in the intermediate layer.

Decreasing the transmissivity in the intermediate layer caused the simulated heads in the intermediate layer to rise, and this caused a corresponding rise in the upper layer. A decrease of 50 percent caused the total number of simulated heads that exceeded the error criterion to increase from 0 to 11 . The model was less sensitive to an increase in transmissivity. An increase of 50 percent caused six of the simulated heads to exceed the error criterion.

Decreasing the conductivity in the upper layer caused the simulated heads to rise because larger horizontal gradients were needed to move ground water through the upper layer of the aquifer. A decrease of 50 percent caused the number of simulated heads in the upper layer that exceeded the error criterion to increase from 0 to 7 . The model was less sensitive to increases in horizontal hydraulic conductivity. An increase of 50 percent caused three of the simulated heads to exceed the error criterion.

Decreasing the vertical leakance by 50 percent caused the total number of simulated heads that exceeded the error criterion to increase from 0 to 6 . An increase of 50 percent caused the number of heads that exceed the error criterion to increase from 0 to 3 in the upper layer, whereas the intermediate layer was unaffected.

\section{Flow Path Analysis}

The direction and rate of ground-water movement was computed using the USGS program MODPATH (Pollock, 1989). This program uses particle-tracking techniques in combination with the MODFLOW computed flow rates between model cells. Particle starting locations were specified and the particles were then tracked forward to areas of discharge. A porosity of 25 percent was assumed for both the upper and intermediate layers of the surficial aquifer; other porosities would give exactly the same direction of ground-water flow, but the rate of movement would change. Reducing the simulated porosity by half would double the simulated velocity. Likewise, doubling the simulated porosity would decrease the simulated velocity by half.

Simulated ground-water flow pathlines for the upper layer are shown in figure 29. At OU3, the leaking stormwater drains divide ground-water flow into several small areas with distinct flow directions. The ground-water velocities are very low, averaging about $2 \mathrm{ft} / \mathrm{yr}$. (The distance between dots along selected pathlines indicates 40 years of traveltime.) These slow velocities are primarily the result of the low horizontal hydraulic conductivity and, secondarily, the result of low hydraulic gradients due to the low recharge rate in the extensively paved areas.

Simulated ground-water flow in the intermediate layer beneath OU3 is generally eastward toward and discharges into the St. Johns River (fig. 30). Ground-water flow velocities are significantly higher in this layer than in the upper layer. North of the low-permeability channel-fill deposits, the velocity is about $35 \mathrm{ft} / \mathrm{yr}$; south of the deposits, about $12 \mathrm{ft} / \mathrm{yr}$. Velocities in the intermediate layer are higher in the northern part of OU3 because the horizontal hydraulic gradients are higher, as discussed earlier. Within the low-permeability channel-fill deposits, the ground-water flow changes direction and slows down significantly. The flow lines converge toward the docking facility where ground water is discharging due to the dredging that occurred previously. 


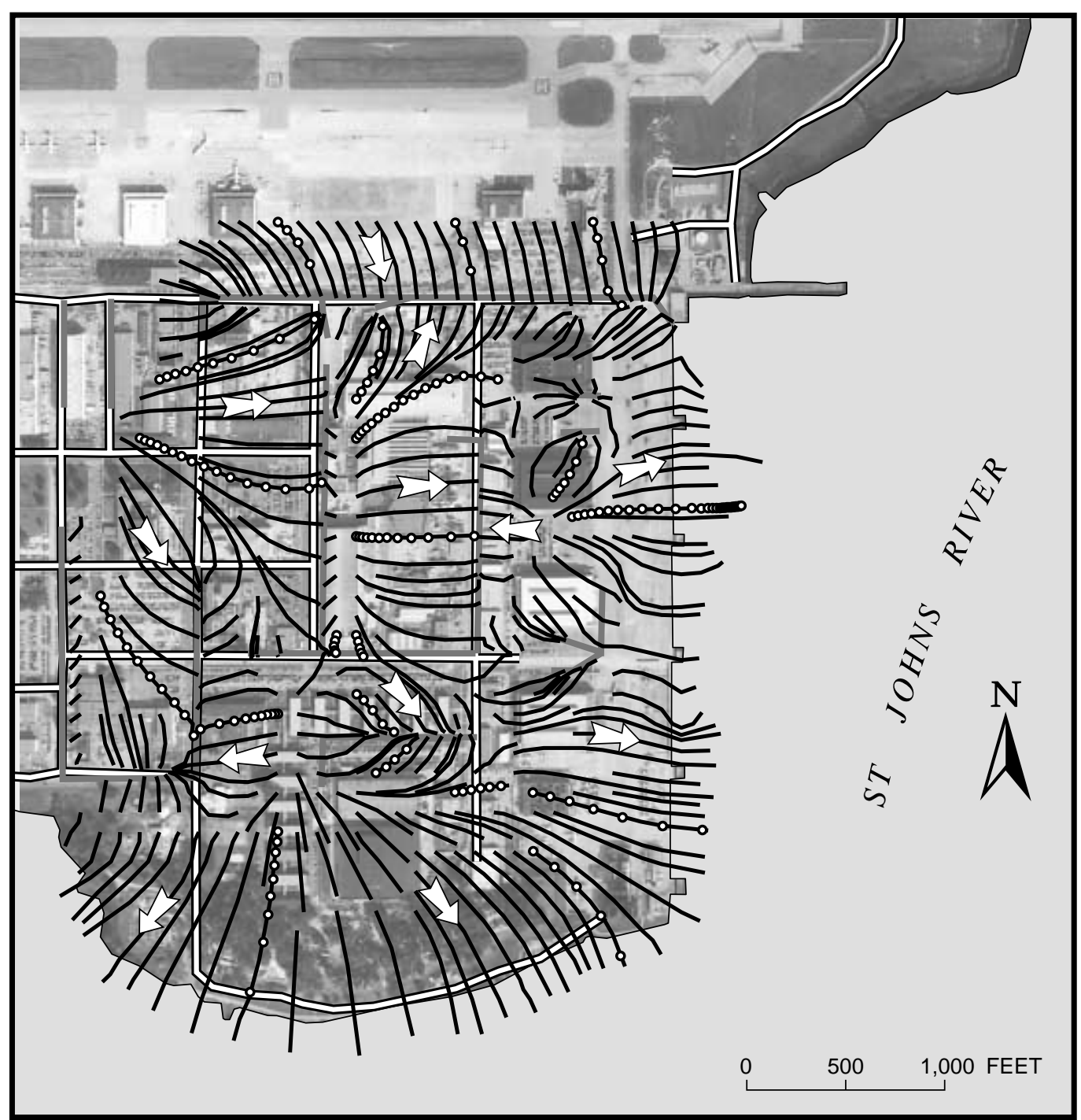

EXPLANATION

$\longrightarrow$ P -0 PARTICLE PATHLINE-Shows simulated ground-water flow path in the upper layer. Distance between dots represents a travel time of 40 years

STORMWATER DRAIN ASSUMED TO BE LEAKING

2 GROUND-WATER FLOW ARROW-Shows direction of ground-water flow along pathlines

Figure 29. Particle pathlines representing ground-water flow directions in the upper layer of the surficial aquifer at Operable Unit 3. 
Simulated ground-water pathlines are shown in a generalized section in figure 31 . The generalized section is along row 40, between columns 58 and 107; the pathlines are projected along this row by the method described in Pollock (1989). As discussed above, the leaking stormwater drains divide the flow in the upper layer into several small areas where ground water moves toward and discharges into a nearby drain. In contrast, the flow in the intermediate layer is more regional. In this layer, ground water moves laterally under OU3 to beneath the St. Johns River, then vertically upward through the upper layer to discharge through the river bottom.

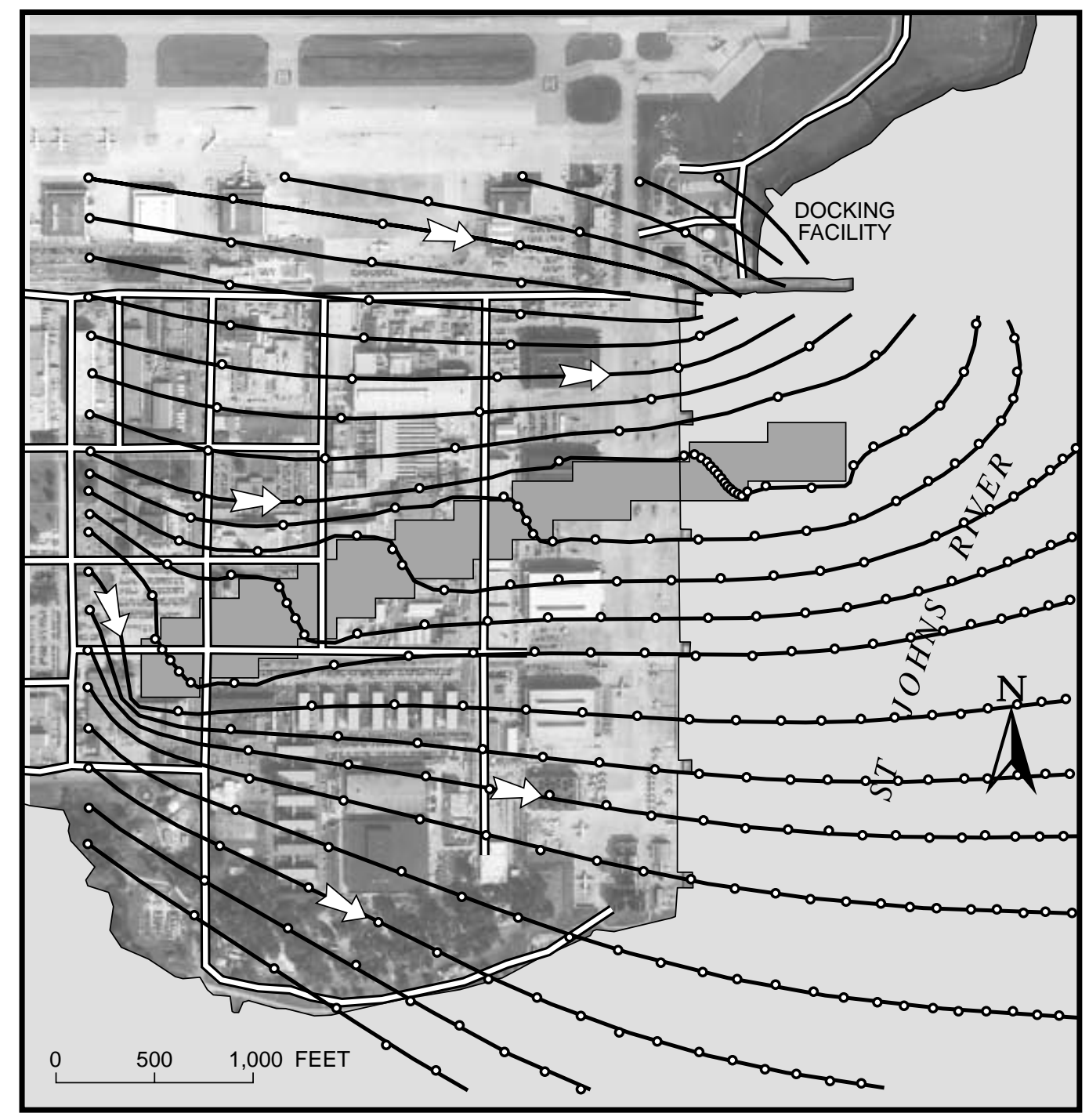

\section{EXPLANATION}

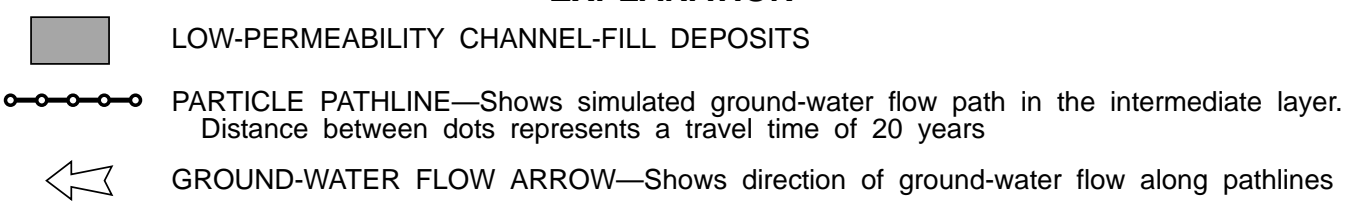

Figure 30. Particle pathlines representing ground-water flow directions in the intermediate layer of the surficial aquifer at Operable Unit 3. 


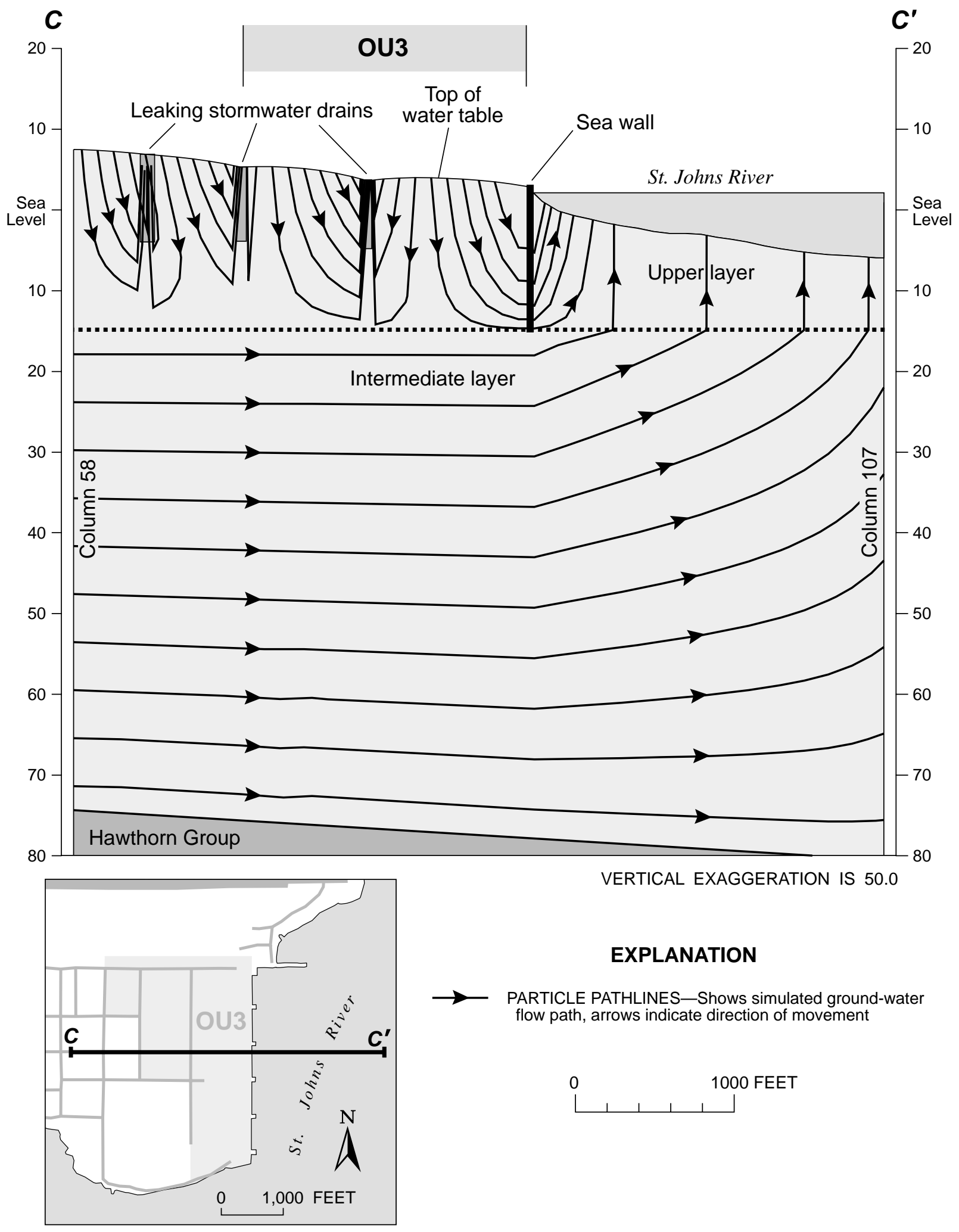

Figure 31. Generalized section showing particle pathlines at Operable Unit 3. 


\section{SUMMARY AND CONCLUSIONS}

The Naval Air Station, Jacksonville occupies 3,800 acres adjacent to the St. Johns River in Duval County, Fla. OU3 occupies 134 acres on the eastern side of the Station and has been used for industrial and commercial purposes since World War II. Ground water contaminated by chlorinated organic compounds has been detected in the surficial aquifer at OU3. The Navy and USGS conducted a cooperative hydrologic study to evaluate the potential for ground-water discharge to the neighboring St. Johns River.

At the Station, the surficial aquifer is exposed at land surface and thus forms the uppermost permeable unit. The aquifer is composed of sedimentary deposits of Pliocene to Holocene age. These deposits range in thickness from 30 to $100 \mathrm{ft}$ and consist of unconsolidated silty sands interbedded with local thin beds of clay. The low-permeability clays of the Hawthorn Group form the base of the aquifer.

The USGS previously conducted a ground-water investigation at the Station that included the development and calibration of a 1-layer regional ground-water flow model using MODFLOW. For this investigation, the regional model was recalibrated using additional data collected since the original calibration. After recalibration, simulated heads matched measured heads in 130 of 131 wells to within the calibration criterion of $2.5 \mathrm{ft}$. The recalibrated model was then used to establish the boundaries for a smaller subregional model at OU3.

Within the subregional OU3 model area, the surficial aquifer is composed of distinct upper and intermediate layers. The upper layer extends from land surface to a depth of approximately $15 \mathrm{ft}$ below sea level; the intermediate layer extends from the upper layer down to the top of the Hawthorn Group. In the northern and central parts of OU3, the upper and intermediate layers are separated by a low-permeability clay layer. Horizontal hydraulic conductivities in the upper layer were determined by aquifer tests and ranged from 0.19 to $3.8 \mathrm{ft} / \mathrm{d}$. The horizontal hydraulic conductivity in the intermediate layer was determined to be $20 \mathrm{ft} / \mathrm{d}$ from one aquifer test.

An extensive stormwater drainage system is present at OU3 and the surrounding area. Some of the stormwater drains have been documented to be draining ground water and some are suspected of draining ground water from the upper layer of the surficial aquifer. The bottom of and water-level surface in the drains are below the water table; thus, the drains can remove ground water from the aquifer but cannot act as a source of water to the aquifer. The depth to the bottom of the drains varies, but is approximately 5 to $10 \mathrm{ft}$ below land surface.

The subregional model area was divided into 78 rows and 148 columns of square model cells that were $100 \mathrm{ft}$ on each side. Vertically, the surficial aquifer was divided into two model layers. The upper model layer represents the upper layer of the aquifer and the lower model layer represents the intermediate layer. Steady-state groundwater flow conditions were assumed. The model was calibrated to head data collected on October 29 and 30, 1996. After calibration, the model matched all 67 measured heads to within the calibration criterion of $1 \mathrm{ft}$; and 48 of 67 simulated heads (72 percent) were within $0.5 \mathrm{ft}$.

Model-simulated recharge rates ranged from $0.4 \mathrm{in} / \mathrm{yr}$ in areas that were largely paved to $13.0 \mathrm{in} / \mathrm{yr}$ in irrigated areas. Simulated hydraulic conductivities in the upper layer at OU3 ranged from $0.5 \mathrm{ft} / \mathrm{d}$ in the north to $1.0 \mathrm{ft} / \mathrm{d}$ in the south. Simulated vertical leakance between the upper and intermediate layers ranged from $1.0 \times 10^{-6} \mathrm{~d}^{-1}$ in an area with low-permeability clays to $4.3 \times 10^{-2} \mathrm{~d}^{-1}$ in an area that had been dredged. Simulated transmissivities in the intermediate layer ranged from $25 \mathrm{ft}^{2} / \mathrm{d}$ in an area of low-permeability channel-fill deposits to about $1,200 \mathrm{ft}^{2} / \mathrm{d}_{\text {in }}$ most of OU3. Simulated riverbed conductances ranged from 4 to $60 \mathrm{ft}^{2} / \mathrm{d}$ and simulated bottom conductances of the stormwater drains ranged from 5 to $20 \mathrm{ft}^{2} / \mathrm{d}$.

The direction and velocity of ground-water flow was determined using particle tracking techniques. Groundwater flow in the upper layer was generally eastward toward the St. Johns River. However, leaking stormwater drains at OU3 locally modified the flow system to create small areas with flow directions diverted to the drains. The flow velocities in the upper layer at OU3 were slow, averaging about $2 \mathrm{ft} / \mathrm{yr}$. The slow velocities were primarily the result of the low horizontal hydraulic conductivity and, secondarily, the result of the low recharge rate. The simulated rate at which ground water leaked into the stormwater drains was low, averaging about $0.0011 \mathrm{ft}^{3} / \mathrm{s}$ per $100 \mathrm{ft}$ of stormwater drainage conduit. Ground-water flow in the intermediate layer moved eastward beneath OU3 toward, and discharging into, the St. Johns River. Flow velocities were significantly higher in this layer than in the upper layer. The velocity was about 35 and $12 \mathrm{ft} / \mathrm{yr}$ in the northern and southern parts of OU3, respectively. 


\section{REFERENCES}

Bradner, L.A., Murray, L.C., Phelps, G.G., and Spechler, R.M., 1992, Potentiometric surface of the Upper Floridan aquifer in the Saint Johns Water Management District and vicinity, May 1992: U.S. Geological Survey Open-File Report 92-466, 1 sheet.

Brooks, H.K., 1981, Physiographic divisions, State of Florida: University of Florida, Center for Environmental and Natural Resources Programs, 1 sheet.

Davis, J. H., Planert, Michael, and Andrews, W.J., 1996, Simulation of ground-water flow at the U.S. Naval Air Station, Jacksonville, Florida, with an evaluation of changes to ground-water flow caused by proposed remedial designs at Operable Unit 1: U.S. Geological Survey Open-File Report 96-597, 47 p.

Fairchild, R.W., 1972, The shallow-aquifer system in Duval County, Florida: Florida Bureau of Geology Report of Investigations no. $59,50 \mathrm{p}$.

_ 1977, Availability of water in the Floridan aquifer in southern Duval and northern Clay and St. Johns Counties, Florida: U.S. Geological Survey Water-Resources Investigations Report 76-98, 53 p.

Freeze, R.A., and Cherry, J.A., 1979, Groundwater: Prentice-Hall, 604 p.

Geraghty and Miller, 1991, Navy installation restoration program plan, Naval Air Station, Jacksonville, Florida, volume 1, organization and planning: 13-0019-IRPP.

Harbaugh, A.W., 1990, A computer program for calculating subregional water budgets using results from the U.S. Geological Survey Modular Three-Dimensional Finite-Difference Ground-Water Flow Model: U.S. Geological Survey Open-File Report 90-392, 46 p.

Healy, H.G., 1975, Terraces and shorelines of Florida: Florida Department of Natural Resources, Bureau of Geology: Map Series no. 71,1 sheet.

Hseih and Freckleton, 1993, Documentation of a computer program to simulate horizontal-flow barriers using the U.S. Geological Survey's modular three-dimensional finite-difference ground-water flow model: U.S. Geological Survey OpenFile Report 92-477, 32 p.

Leve, G.W., 1978, Altitude and configuration of the top of the Floridan aquifer, Duval County, Florida: U.S. Geological Survey Open-File Report 77-114, 1 sheet.

Marella, R.L., 1993, Water withdrawals, use, and trends in Florida, 1990: U.S. Geological Survey Water-Resources Investigations Report 92-4140, 38 p.

Miller, R.A., 1986, Hydrologic framework of the Floridan aquifer system in Florida an in parts of Georgia, Alabama, and South Carolina: U.S. Geologicsl Survey Professional Paper 1403-B, 91 p.

McDonald, M.G., and Harbaugh, A.W., 1988, A modular three-dimensional finite-difference ground-water flow model: U.S. Geological Survey Techniques of Water-Resources Investigations, book 6, chapter A1, variously paged.

Miller, J.A., 1986, Hydrogeologic framework of the Floridan aquifer system in Florida, and in parts of Georgia, Alabama, and South Carolina: U.S. Geological Survey Professional Paper 1403-B, 91 p.

Pollock, D.W., 1989, Documentation of computer programs to compute and display pathlines using results from the U.S. Geological Survey modular three-dimensional finite-difference ground-water flow model: U.S. Geological Survey Open-File Report 89-381, $188 \mathrm{p}$.

Scott, T.M., 1988, The lithostratigraphy of the Hawthorn Group (Miocene) of Florida: Florida Geological Survey Bulletin no. $59,148 \mathrm{p}$.

Snell, L.J., and Anderson, W., 1970, Water resources of northeast Florida: Florida Bureau of Geology, Report of Investigations no. $54,77 \mathrm{p}$.

Spechler, R.M., 1994, Saltwater intrusion and quality of water in the Floridan aquifer system, Northeastern Florida: U.S. Geological Survey Water-Resources Investigations Report 92-4174, 76 p.

Stringfield, V.T., 1966, Artesian water in Tertiary limestone in the Southeastern States: U.S. Geological Survey Professional Paper 517, $226 \mathrm{p}$.

U.S. Navy Department, Southern Division Naval Facilities Engineering Command, 1994, Remedial investigation and feasibility study, Operable Unit 3, Naval Air Station, Jacksonville: South Division Contract N62467-89-D-0317, 142 p.

U.S. Navy Department, Southern Division Naval Facilities Engineering Command, 1998, Engineering evaluation of areas with elevated groundwater contamination, Operable Unit 3, Naval Air Station, Jacksonville: South Division Contract N6246789-D-0317/076, $107 \mathrm{p}$. 